\title{
Yurt Dışında Yabancı Dil Olarăk Türkçe Öğretmek: Sorunlar ve Çözüm Önerileri
}

\author{
Hatice Altunkaya*
}

Makale Geliş Tarihi: 24/11/2020

Makale Kabul Tarihi: 24/01/2021

DOI: $10.35675 /$ befdergi. 830898

$\ddot{O} z$

Bu çalışmanın amacl, yurt dişında yabancı dil olarak Türkçe öğretilirken yaşanan sorunları tespit etmek ve bunlara çözüm önerileri sunmaktır. Çalışmada, nitel araştırma desenlerinden olgu bilim deseninden yararlanılmıştır. Araştırmada öne çıkan sorunların 'tek tip ses kaydının bulunması, ses kaydl, dinleme cihazı yokluğu ya da yetersizliği', ‘ögrencilerin kendi dillerinde olmayan sesleri seslendirmede yaşadıkları zorluğa bağll sorunlar', 'sesli okuma sürecinde telaffuz, vurgu, tonlama hatalarl, ders kitabı haricinde okuma metni bulunmaması', 'yazma özyeterliliği düşüklüğ̈̈, kaygısl, ilgisizlik, olumsuz tutum, dil bilgisi hataları, 'önceden öğrenilen yabancı dil konularının ya da ana dilin ileriye ket vurmasl, öğrencilerin olumsuz tutumu, motivasyon eksikliği, kaygl düzeyi yüksekliği', 'teknoloji yetersizliği, ders programı sorunları' bulunduğu tespit edilmiştir. Bu sorunlara yönelik çözüm önerileri getirilmiştir.

Anahtar Kelimeler: Dinleme, konuşma, okuma, yabancı dil olarak Türkçe öğretimi, yazma

\section{Instruction of Turkish as a Foreign Language Abroad: Problems and Recommendations}

\begin{abstract}
The present study aimed to identify the problems encountered during the instruction of Turkish as a foreign language abroad and to offer solutions for these problems. In the study, phenomenology, a qualitative research design, was employed. In the study, it was determined that 'the employment of a single audio recording type, audio recording, lack or inadequacy of listening devices', 'problems associated with the difficulties that students experienced in vocalizing alien sounds, 'pronunciation, accent, intonation errors when reading aloud, only reading the texts available in the textbook,' ' low writing self-efficacy, writing anxiety, lack of interest, negative attitudes', 'grammatical errors, the obstraction of development by previously learned foreign language topics or the native language, negative student attitudes', 'lack of motivation, high anxiety levels, lack of technical and technological support, and problems associated with the curricula'. Solutions for these problems have been suggested.
\end{abstract}

Keywords: Listening, reading, speaking, teaching Turkish as a foreign language, writing

\footnotetext{
* Aydın Adnan Menderes Üniversitesi, Aydın, Türkiye, hatice.altunkaya@adu.edu.tr, ORCID: 00000003-4498-194X (iD
}

Kaynak Gösterme: Altunkaya, H. (2021). Yurt dışında yabancı dil olarak Türkçe öğretmek: Sorunlar ve çözüm önerileri. Bayburt Eğitim Fakültesi Dergisi, 16(Özel Say1), 1-33. https://doi.org/10.35675/befdergi.830898 


\section{Giriş}

Artan iletişim teknolojileri, sosyal medya kullanımları, ikili ilişkiler, ticaret gibi nedenlerle birden fazla dil öğrenme gereksinimi bugün dünyanın yadsınamaz bir gerçeğidir. Dil öğretimi, sadece dilin kurallarının ve kelimelerinin öğretilmesi değil o dile ilişkin kültürün, değerlerin, tarihin, sanatın tanıtımını da içerir. Bu bağlamda Türkçenin yabancı dil olarak öğretilmesi hususunda Yunus Emre Enstitüsü büyük bir misyonu yerine getirmektedir. Dünyada 58 farklı yerde merkezi bulunan Enstitü, merkezi bulunmayan ülkelerdeki üniversitelerle de iş birliği yapmakta ve Türkçenin öğretimini desteklemektedir. Yurt dışında çeşitli üniversitelerde bulunan Türk Dili ve Edebiyatı bölümleri, Türkoloji kürsüleri, Maarif Vakfina bağlı okullar da Türkçenin öğretildiği yerler arasındadır. Yabancı dil olarak Türkçe öğrenme isteği çeşitli nedenlerle sürekli bir artış göstermektedir. Durmuş (2013) bu artışın nedenlerini Türkiye'nin; Orta Doğu, Doğu Avrupa, Asya, Kafkaslar, Orta Asya, Akdeniz, Karadeniz hatta İslam Dünyası gibi önemli uluslararası çalışma sahalarının her biri için ayrı ayrı ilgi odağı olması; uluslararası literatürü fazlasıyla meşgul eden petrol, doğalgaz ve bunların dünya pazarlarına ulaştırılması; terör, tehdit unsuru olarak öne çıkan savaşlar vb. belirli meselelerle ilgili olarak da bölgede önemli bir ilgi odağı olarak görülmesi olarak sıralamış ve doğal olarak bu ilginin, önemli ölçüde Türkçe öğrenme talebi de doğurduğunu ifade etmiştir. Erdem (2009) de Türkçenin, dünyanın farklı coğrafyalarında iki yüz elli milyona yakın insanın kullandığı yaygın bir dil olduğunu, ayrıca dünyada en çok konuşulan yedi dilin (diğerleri Çince, Hintçe, İspanyolca, İngilizce, Fransızca ve Rusça) arasında yer aldığını belirtmiş ve bu denli yaygın olarak kullanılan bir dilin, yabancılar tarafından öğrenilmek istenmesinin doğal olduğuna dikkat çekmiştir.

Türkçenin yabancı dil olarak öğretilmesi sürecinde yaşanan sorunların tespit edilmesi ile ilgili önceki çalışmalar başlıca iki konuya odaklanmış durumdadır. Birçok çalışma, Türkiye'de Türkçenin yabancılara öğretiminde karşılaşılan sorunlara yönelik sorunları incelerken bazı çalışmalar da bir ülkede yaşanan sorunların tespitine yönelik gerçekleştirilmiştir. Açık (2008) Ankara, Gazi ve Ege Üniversiteleri Türkçe Öğretim Merkezlerinde Türkçe öğrenen 100 öğrenciye anket uygulamak ve sonrasında anket bulgularını desteklemek için birebir görüşmeler yapmak suretiyle sorunları tespit etmiştir. Candaş Karababa (2009) yabancılara Türkçe öğretimi veren üniversitelere bağlı iki ve MEB' e bağlı özel bir dil okulunda Türkiye'de öğretim veren öğretim elemanlarından 18 öğretim elemanı ile görüşme gerçekleştirmiş ve Türkçenin yabancı dil olarak öğretilmesinde yaşanan güçlükleri tespit etmiştir. Maden ve İşcan (2011) yabancı dil olarak Türkçe öğretimi amaç ve sorunlarını Hindistan örneği ile belirlemeye çalıştıkları araştırmalarında Hindistan Jawarhalal Nehru Üniversitesinde Türkçe öğrenen öğrencilerden yarı yapılandırılmış form aracılığ 1 ile veri toplamışlar ve neticesinde "katılımcıların Türkçeyi öğrenme amaçları arasında bir meslek sahibi olma, Türk tarihini, kültürünü ve medeniyetini merak ve tanıma, çok dilli olma, Türkiye'yi tanıma ve ziyaret etmenin öncelikli olduğu belirlenmiş buna ek olarak, katılımcıların Türkçe öğrenirken daha çok gramer alanında, konuşma ve kelime hazinesi eksikliği alanlarında sorun yaşadıkları sonucuna ulaşmışlardır. Durmuş (2013) Türkçenin yabancılara öğretilmesi sürecinde karşılaşılan sorunlar ve bu sorunların çözüm önerilerine dair ilgili literatürde ortaya 
konulan çalışmaları taramış ve Türkçenin yabancı dil olarak öğretimi uygulamaları yoluyla elde ettiği deneyimleri ile gözlemlerinden yararlanarak bir çalışma ortaya koymuştur. Çalışmada, sorunları 12 maddede toplayarak bunlara yönelik çözüm önerilerini sunmuştur. Okur ve Onuk (2013) çalışmalarında ülkemizde yabancılara Türkçe öğretiminde yaşanan sorunları değerlendirmişlerdir. Yağcı (2017) Belarus’ta Türkçenin öğretiminde karşılaşılan sorunları tespit ederek çözüm önerilerinde bulunmuştur. Benzer şekilde ayrı ayrı ülkelerde karşılaşılan sorunların tespitine ve çözüm önerilerine ilişkin çeşitli araştırmalar (Başutku, Kaya \& Tomak, 2016; Özdemir, Ruşid, Çevik, Yerlikaya \& Ali, 2016; İpek, 2016; Sevindik, Okur \& Curtomer, 2016, Gürler, Türkyılmaz, Türkyılmaz \& Tamkoç, 2016; Karazeybek, 2016; Salduz \& Akbulut, 2016; Yörüsün, Kardaş \& Erdoğan, 2016; İbragiç, 2017) bulunmaktadır.

Türkçe öğrenme isteği, Türkiye'nin stratejik önemine binaen artmakta ve buna paralel olarak son yıllarda gelişen Türk dizi sektörü de artan talebe büyük katk1 sunmaktadır. Boylu ve Başar (2015) İran'da yapmış oldukları çalışmalarında öğrencilerin dil öğrenme sürecinde dizi/filmlerin faydalarının bilincinde oldukları ve sadece televizyon izleyerek B1, B2 ve C1 kuruna kayıt yaptırdıklarını, buna ek olarak öğrencilerin \%92,72'sinin Türk kanallarını izlemenin Türkçe dinleme ve konuşma becerisi üzerinde olumlu etkisinin olduğunu düşündüklerini, öğrencilerin \%50,10'unun da Türkçe öğrenmek için Türk kanallarını izlediğini ortaya koymuşlardır.

Türkçe öğrenme talebinde bulunan öğrencilere çağdaş eğitim yaklaşım, yöntem ve teknikleri bağlamında öğrenen özelliği gerçeğini ön planda tutarak eğitim vermek, eğitimde hedeflenen başarıya ulaşabilmek için son derece önemlidir. $\mathrm{Bu}$ süreçte başarılı olabilmenin anahtarı, sorunların tespit edilmesi ve bunlara yönelik çeşitli öneriler getirilebilmesidir. Türkçe öğretiminde yaşanan sorunları tespit etme hususunda var olan çalışmaların, öncelikle Türkiye'de Türkçe öğretiminde karşılaşılan sorunlara yönelik olduğu, yurtdışında yapılan çalışmaların da ayrı ayrı ülkelere ilişkin olduğu tespit edilmiştir. $\mathrm{Bu}$ bağlamda, ilgili literatürde farklı ülkelerde Türkçenin öğretiminde yaşanan ortak sorunların tespitine yönelik bir çalışmaya rastlanılmadığından bu çalışma, alandaki önemli bir boşluğu doldurmaya hizmet edebilecektir. Yurt dişında Türkçe öğretimi sahasında farklı ülkelerde görev yapan öğretim elemanlarından elde edilen nitel veriler, alandaki sorunları ayrıntılı olarak tespit edebilme ve bunlara çözüm önerileri getirebilme imkânı sağlar. Nitekim Demirel (1993) yabancı dil öğretimi uygulamalarının başarısının; temel alınan ilkeler ve yöntemlerin sınıf içindeki kullanım koşullarına bağlı olduğunu; temel ilkelerin; dil ve eğitim bilimcilerin çeşitli araştırmalar sonucu ulaştıkları bulgulara göre oluşturulmuş bir dizi önermeden oluştuğunu ifade etmektedir. Yurt dışında Türkçenin öğretiminde yaşanan sorunların ve bunlara yönelik çözüm önerilerinin birebir öğretimi gerçekleştiren öğretim elemanları aracılığı ile tespit edilmesi, Demirel (1993) tarafindan ifade edilen bir dizi önermenin ortaya çıkmasına hizmet edebilecek ve böylece Türkçenin öğretimi uygulamalarına katkı sunabilecektir. Çalışmada ortaya konulacak sorunlar ve çözüm önerileri ile yurt dışında Türkçe öğretimi sürecine bir ayna tutulmuş olacaktır. Sorunların ayrıntılı bir şekilde tespit edilmesi ve getirilen önerilerin değerlendirilmesiyle birlikte öğreticiler öğretimlerini tasarlayabilir, araştırmacılar bunlar üzerinde çalışabilir, yöneticiler, 
program yapımcıları ile kitap yazarları bu sorunlar ve çözüm önerileri doğrultusunda girişimde bulunabilirler. Bu girişimler de dil başarısına giden yolun anahtarı olarak görülebilir. Bu bilgiler ışı̆̆ında araştırmanın amacı ve bu amaç doğrultusunda belirlenen sorular aşağıda sunulmuştur:

\section{Çalıșmanın Amacı}

Bu çalışmanın amacı, yurt dışında yabancı dil olarak Türkçe öğretilirken karşılaşılan sorunları tespit etmek, bu sorunlara çözüm önerileri sunmaktır. Bu temel amaç doğrultusunda aşağıdaki soruların yanıtları aranmıştır:

1. Türkçenin yabancı dil olarak yurt dışında öğretiminde dinleme, konuşma, okuma, yazma eğitimi ve dil bilgisi öğretimine yönelik sorunlar nelerdir?

2. Türkçenin yabancı dil olarak yurt dışında öğretiminde dinleme, konuşma, okuma, yazma eğitimi ve dil bilgisi öğretimindeki sorunlara yönelik çözüm önerileri nelerdir?

3. Türkçenin yabancı dil olarak yurt dışında öğretiminde, çalışılan üniversitelerin uygulamalarına bağlı sorunlar nelerdir?

4. Türkçenin yabancı dil olarak yurt dışında öğretiminde, üniversitelerin uygulamalarına bağlı sorunlara yönelik çözüm önerileri nelerdir?

\section{Yöntem}

\section{Araştırma Deseni}

Çalışmada nitel araştırma desenleri arasında bulunan olgu bilim deseninden yararlanılmıştır. Cropley’ye göre olgubilim (phenomelogy) çalışmaları farkında olduğumuz ancak derinlemesine ve ayrıntılı bir anlayışa sahip olmadığımız olgulara odaklanmaktadır. Olgubilim araştırmalarında veri kaynakları, araştırmanın odaklandığı olguyu yaşayan ve bu olguyu dişa vurabilecek veya yansitabilecek bireyler ya da gruplardır (Aktaran Yıldırım \& Şimşek, 2005). Bu çalışma için olgubilim deseninden yararlanma gerekçesi, yurt dışında Türkçe öğretimi sürecinde yaşanan sorunları ve bu sorunlara bağlı çözüm önerilerini derinlemesine ve ayrıntılı bir şekilde bizzat bu işi yapan öğretim elemanları aracılığı ile ortaya koyabilme amacidır.

Araştırma için gerekli etik kurul izni, Aydın Adnan Menderes Üniversitesi Eğitim Araştırmaları Etik Kurulundan 06.10.2020 tarihli ve 84982664-050.01.04 sayılı yazı ile alınmıştır.

\section{Çalışma Grubu}

Tablo 1.

Araştırmanın Katılımcılarına Ait Bilgiler

\begin{tabular}{|c|c|c|c|c|c|c|c|}
\hline & Görevi & Görev Yeri & Yaşı & Cinsiyeti & $\begin{array}{c}\text { Kaç Yıldır } \\
\text { Türkçe } \\
\text { Öğretiyor }\end{array}$ & $\begin{array}{c}\text { Mezun Olunan } \\
\text { Bölüm }\end{array}$ & $\begin{array}{c}\text { Öğrencilerinin } \\
\text { yaş grubu }\end{array}$ \\
\hline Ö.1. & Okutman & Hindistan & 29 & Erkek & 4 & $\begin{array}{c}\text { Türk Dili ve } \\
\text { Edebiyatı }\end{array}$ & $18-30$ \\
\hline Ö.2. & Dr. Öğr. & Cezayir & 46 & Kadın & 5 & Türk Dili ve & $18-25$ \\
\hline
\end{tabular}




\begin{tabular}{|c|c|c|c|c|c|c|c|}
\hline & Görevlisi & & & & & Edebiyatı & \\
\hline Ö.3. & $\begin{array}{l}\text { Öğretim } \\
\text { Görevlisi }\end{array}$ & Pakistan & 46 & Kadın & 10 & $\begin{array}{c}\text { Türk Dili ve } \\
\text { Edebiyatı }\end{array}$ & $17-46$ \\
\hline Ö.4 & $\begin{array}{c}\text { Öğretim } \\
\text { Üyesi }\end{array}$ & Rusya & 39 & Kadın & 5 & $\begin{array}{c}\text { Türk Dili ve } \\
\text { Edebiyatı }\end{array}$ & $18-27$ \\
\hline Ö.5 & Okutman & Filistin & 26 & Kadın & 4 & $\begin{array}{c}\text { Türk Dili ve } \\
\text { Edebiyatı }\end{array}$ & $13-65$ \\
\hline Ö.6 & Okutman & Cezayir & 37 & Kadın & 10 & $\begin{array}{c}\text { Türk Dili ve } \\
\text { Edebiyatı }\end{array}$ & $18-23$ \\
\hline Ö.7 & Okutman & Ürdün & 27 & Erkek & 2 & $\begin{array}{l}\text { Çağdaş Türk } \\
\text { Lehçeleri ve } \\
\text { Edebiyatları }\end{array}$ & $18-22$ \\
\hline Ö.8 & Okutman & Hindistan & 33 & Kadın & 10 & $\begin{array}{c}\text { Türk Dili ve } \\
\text { Edebiyatı }\end{array}$ & $17-25$ \\
\hline Ö.9 & $\begin{array}{c}\text { Öğretim } \\
\text { Üyesi }\end{array}$ & Hindistan & 45 & Erkek & 1 & $\begin{array}{c}\text { Türk Dili ve } \\
\text { Edebiyatı }\end{array}$ & $18-22$ \\
\hline Ö.10 & $\begin{array}{c}\text { Öğretim } \\
\text { Üyesi }\end{array}$ & $\begin{array}{l}\text { Bosna- } \\
\text { Hersek }\end{array}$ & 35 & Erkek & 7 & Türkçe Eğitimi & $18-22$ \\
\hline Ö.11 & $\begin{array}{l}\text { Öğretim } \\
\text { Üyesi }\end{array}$ & Cezayir & 48 & Erkek & 5 & $\begin{array}{c}\text { Türk Dili ve } \\
\text { Edebiyatı }\end{array}$ & $18-30$ \\
\hline Ö.12 & $\begin{array}{l}\text { Öğretim } \\
\text { Görevlisi }\end{array}$ & Etiyopya & 50 & Erkek & 10 & $\begin{array}{c}\text { Türk Dili ve } \\
\text { Edebiyatı }\end{array}$ & $18-24$ \\
\hline Ö.13 & $\begin{array}{l}\text { Öğretim } \\
\text { Görevlisi }\end{array}$ & Lübnan & 33 & Kadın & 3 & $\begin{array}{c}\text { Türk Dili ve } \\
\text { Edebiyatı }\end{array}$ & $18-55$ \\
\hline Ö.14 & $\begin{array}{l}\text { Öğretim } \\
\text { Görevlisi }\end{array}$ & Cezayir & 31 & Erkek & 9 & Türkçe Eğitimi & $18-21$ \\
\hline Ö.15 & $\begin{array}{c}\text { Öğretim } \\
\text { Üyesi }\end{array}$ & Pakistan & 40 & Kadın & 11 & $\begin{array}{c}\text { Türk Dili ve } \\
\text { Edebiyatı }\end{array}$ & $18-55$ \\
\hline Ö.16 & $\begin{array}{c}\text { Öğretim } \\
\text { Üyesi }\end{array}$ & İran & 31 & Erkek & 8 & Türkçe Eğitimi & $17-26$ \\
\hline Ö.17 & $\begin{array}{l}\text { Öğretim } \\
\text { Üyesi }\end{array}$ & Makedonya & 38 & Kadın & 2 & $\begin{array}{c}\text { Sinıf } \\
\text { Öğretmenliği }\end{array}$ & $19-25$ \\
\hline Ö.18 & $\begin{array}{l}\text { Öğretim } \\
\text { Görevlisi }\end{array}$ & Sudan & 35 & Erkek & 7 & $\begin{array}{c}\text { Türk Dili ve } \\
\text { Edebiyatı }\end{array}$ & $20-25$ \\
\hline
\end{tabular}

Araştırmanın çalışma grubunda Tablo 1'de de görüldüğ̈ gibi 13 Türk Dili ve Edebiyatı Bölümü, 3 Türkçe Eğitimi, 1 Sınıf Eğitimi ile 1 Çağdaş Türk Lehçeleri ve Edebiyatları mezunu bulunmaktadır. Hindistan'da görev yapan 3, Pakistan'da 2, Cezayir'de 4, İran, Makedonya, Sudan, Lübnan, Etiyopya, Bosna-Hersek, Ürdün, Filistin ve Rusya'dan birer kişi olmak üzere çalışma grubunda toplam 12 değişik ülkede görev yapan 9 kadın 9 erkek olmak üzere 18 Türkçe öğreticisinin düşüncesine başvurulmuştur.

\section{Veri Toplama Aracı}

Araştırmanın verileri, araştırmacı tarafından ilgili literatürün taranması sonrası hazırlanan yarı yapılandırılmış görüşme formu ile elde edilmiştir. Formda yer alan sorular hazırlanırken soruların anlaşılabilir, konuyu detayları ve derinliği ile ortaya 
koyabilecek açık uçlu sorular olmasına, yabancı dil eğitimindeki tüm becerileri kapsamasına, bu becerilerin dilde edinim sırasına göre soruların mantıksal olarak düzenlenmesine dikkat edilmiştir. Sorular hazırlandıktan sonra 6 Türkçe eğitimi uzmanının görüşüne başvurulmuştur. $\mathrm{Bu}$ uzmanlardan 4 tanesinin yurt dişında yabancı dil olarak Türkçe öğretimi tecrübesi bulunmakta, bir tanesi Türkçe Öğretimi Araştırma ve Uygulama Merkezi Müdürlüğü yapmakta, bir tanesi de Türkçe eğitimi alanında Dr. Öğretim Üyesi olarak görev yapmakta ve ilgili alanda çalışmalarda bulunmaktadır. Görüşme formuna son şekli uzmanlardan gelen öneriler doğrultusunda verilmiştir. Başlangıçta altı ana bölüm (dört temel dil becerisi, dil bilgisi ve yurt dışında çalışılan kuruma bağlı sorunlar, çözümler) ve bunlardan ilk beşine bağlı alt başlıklar sorusu şeklinde belirlenen formda, altıncı soru tek başlık olarak düzenlenmişken bu düzenleme uzman görüşleri sonrasında altıncı soruya eklenen alt başlık soruları ile yeniden düzenlenmiş, dil kullanımı düzeltmeleri (dil bilgisi eğitimi yerine öğretimi yazılması önerisi gibi) dikkate alınmıştır. Son düzenleme sonrasında, katılımcı grubunda yer almayan bir eğitimci ile pilot çalışma yapılarak soruların anlaşılabilirliği test edilmişstir.

Punch (2005) görüşmenin, temelde soru sorma ve yanıt alma ile ilgili olduğunu, görüşmenin en çok bilinen türünün bireysel, yüz yüze söz alışverişi şeklinde yapıldığını fakat yüz yüze grup görüşmesi, posta yoluyla, kendi başına yanıtlanan soru formu veya telefon görüşmesi şeklinde de olabildiğini ifade etmektedir. $\mathrm{Bu}$ bağlamda hazırlanan görüşme formları, yurt dışında yabancı dil olarak Türkçe öğreten öğretim elemanlarına elektronik posta yolu ile gönderilmiş ve öğreticiler soruları gönüllülük esasına dayalı olarak ayrıntılı olarak yazarak cevaplamışlar ve akabinde araştırmacıya yanıtlanmış formu yine elektronik posta ile göndermişlerdir.

\section{Verilerin Analizi}

Formlardan elde edilen nitel veriler içerik analizine tabi tutulmuştur. Yıldırım ve Şimşek (2005) içerik analizinde, birbirine benzeyen verilerin belirli kavramlar ve temalar çerçevesinde bir araya getirilerek düzenlenerek verilerin yorumunun yapıldığını ifade etmektedir. Dil ögretimi dört temel dil becerisinin ve dil bilgisinin öğretimine dayandığından temalar bu beceriler doğrultusunda oluşturulmuştur. Her bir beceri alanı ve yabancı dil olarak Türkçe öğretilen üniversitelerin uygulamaları birer tema olarak alınmış ve bu temalara bağlı sorulardan elde edilen veriler analiz edilmiştir.

\section{Geçerlilik ve Güvenilirlik}

Çalışmada, belirlenen temalar altında öğretim elemanlarının görüşleri tırnak içerisinde doğrudan sunularak geçerlik sağlanmıştır. Bu görüşler sunulurken öğretim elemanları Ö. 1, Ö. 2 şeklinde kodlanmıştır.

Güvenilirlik, "olayların farklı gözlemciler tarafından aynı kategoriye bağlanması ya da aynı gözlemci tarafindan farklı zamanlarda aynı kategori ile ilişkilendirilmesidir" (Altunışık, Coşkun, Bayraktaroğlu \& Yıldırım, 2005). Bu bağlamda güvenirliği sağlamak için, araştırmacı dışında yabancı dil olarak Türkçe öğreten iki uzman tarafından formlar ayrıca analiz edilmiştir. Miles ve Huberman'ın 
(1994) güvenirlik formülüne göre \%70'in üzerinde görüş birliğine ulaşılarak analizin güvenilir olduğu sonucuna ulaşılmıştır.

\section{Bulgular ve Yorum}

Araştırmanın amacı, yurt dışında yabancı dil olarak Türkçe öğretimi sürecinde dört temel dil becerisi eğitimi ve dil bilgisi öğretiminde yaşanan sorunlar ile çalışılan üniversitenin uygulamalarına bağlı sorunları tespit etmek, bunlara çözüm önerileri sunmaktır. Temel amaç doğrultusunda elde edilen veriler, genel temalar ekseninde gruplandırılmış ve frekans yüzde analizleri ile birlikte alt problemlerde belirtilen sıra ile aşağıda sunulmuştur:

Tablo 2.

Dinleme Eğitiminde Karşılaşılan Sorunlar

\begin{tabular}{lcc}
\hline Cevaplar & $\mathrm{f}$ & $\%$ \\
\hline Tek tip ses kaydı bulunması, ses kaydı yetersizliği & 9 & 50 \\
Dinleme cihazı yokluğu ya da yetersizliği & 9 & 50 \\
Dinleme kaygısı, özyeterlilik algısı vb. duyuşsal durumlar & 4 & 22 \\
Dinleme metinlerinin öğrenci seviyesine uygun olmayışı & 3 & 16 \\
Dinleme metinlerindeki konuların ilgi çekici olmayışı & 3 & 16 \\
Dinleme metinleri ilgili kurdaki dil bilgisi yapılarına uygun değil & 3 & 16 \\
Dinleme kayıtlarının CD şeklinde olması, son dönem bilgisayarlarda & 3 & 16 \\
CD okuyucu bulunmaması, kayıttan dinleme güçlüğü, internet bağlantısı sıkıntısı & & \\
Eğitim ortamının gürültülü olması nedeni ile dinlemenin sekteye uğraması & 2 & 11 \\
Ana dillerinden aşina olmadıkları sesleri dinlemede yaşanan zorluk & 2 & 11 \\
Dinlemeye ayrılan ders süresi yetersizliği & 2 & 11 \\
Öğretim görevlisinin Türkçeyi yöresel ağı özellikleri ile kullanması & 1 & 5 \\
\hline
\end{tabular}

Dinleme eğitimi sürecinde öğretim elemanları, 'Tek tip ses kaydı bulunması, ses kaydı yetersizliği (\%50)', 'dinleme cihazı yokluğu ya da yetersizliği (\%50)', 'dinleme kaygısı, özyeterlik algısı vb. duyuşsal durumlar (\%22)', 'dinleme metinlerinin öğrenci seviyesine uygun olmayışı (\%16)', 'dinleme metinlerindeki konuların ilgi çekici olmayışı (\%16)', dinleme metinlerinin ilgili kurdaki dil bilgisi yapılarına uygun olmaması (\%16)', 'dinleme kayıtlarının CD şeklinde olması, son dönem bilgisayarlarda $\mathrm{CD}$ okuyucu bulunmaması, kayıttan dinleme güçlügüü, internet bağlantısı sıkıntısı (\%16)', 'eğitim ortamının gürültülü olması nedeni ile dinlemenin sekteye uğraması (\%11)', 'öğrencilerin ana dillerinde olmayan sesleri dinlemede zorluk yaşaması (\%11)', 'dinlemeye ayrılan ders saati süresinin yetersizliği (\%11)' ve 'öğretim görevlisinin Türkçeyi yöresel ağız özellikleri ile kullanması (\%5)’ gibi başlıklarda sorunlar yaşandığını ifade etmişlerdir.

Tablo 2'de görüldüğü gibi dinleme cihazı yokluğu ya da eksikliği gibi teknik sorunları öğretim elemanları sıklıkla yaşamaktadırlar. Bu sorunu Ö.7 "Dinleme eğitimi verebileceğim bilgisayarlı bir sınıf mevcut değil. Farklı bir fakültede var fakat o dersliği de alamadık. Kendi imkânlarımızla telefondan dinleme eğitimi vermeye çalışıyoruz” diyerek görünür kılmıştır. Ö. 13 “Üniversitede TİKA'nın desteğiyle akıllı tahta, projeksiyon, bilgisayar ve diğer teknik araçlar sağlanmasına rağmen okul yönetiminin bunların çoğunu kilitli bir yerde tutması nedeniyle istediğimiz gibi kullanamadık. Kendi bilgisayarımı ve hoparlörümü her gün götürüp 
getirmek zorunda kaldım." diyerek bu konuda yaşanan farklı bir soruna dikkat çekmiştir.

Bunun yanı sıra özellikle dinleme kayıtlarının yetersiz olması, çeşitliliğinin az olması da dile getirilen sorunlar arasındadır. Bu konuyu Ö. 5 "Dinleme kayıtları çok yetersizdir. Sadece mevcut kurların ses kayıtları bulunuyor. Çeşitlilik açısından ve öğrencinin kulağının alışması açısından, ses kayıtları ve dinleme etkinlikleri kısıtlı kalmaktadır." şeklinde belirtmiştir. Ö. 18 de aynı konuyu "Dinleme eğitiminde sadece eğitim setlerinin ses dosyalarıyla sınırlı kalmaktayız" diyerek ifade etmiştir.

Dinleme eğitiminde öğretim elemanlarının yaşadığı sorunlardan bir diğeri de metinlerin seslendirilmesinin özellikle A düzeyinde hızlı olması sorunudur. Ö.4 bu konuyu "Dinleme becerisinde yaşadığım en büyük sıkıntı kitapların CD'sindeki konuşucuların çok hızlı konuştuğundan öğrencilerin pek iyi anlayamamasıdır. Öğrenciler eğer metni anlamıyorlarsa dinleme kaydını tekrar dinletiyorum. Yine anlaşılmazsa onun yerine onların anlayabileceği tarzda yavaş yavaş kendim okuyorum" şeklinde Ö. 5 de yine aynı konuyu "Hâlihazırda olan ses kayıtları öğrencilere çok hızlı ve anlaşılmaz gelmektedir.” şeklinde dile getirmiştir. Dinleme metinlerinin seviyeye uygun hazırlanmadığı ile ilgili veriler de dikkat çekicidir. $\mathrm{Bu}$ konuda Ö.13 "Yedi İklim setinde öğrencilerin üst seviyelerde göreceği dil bilgisi kurallarını içeren metinler ilk seviyelerde veriliyor. Bu durum öğrencinin soru sormasına, o dil bilgisini hemen öğrenmek istemesine neden oluyor. Örneğin A1 seviyesi birinci ünitede tanışmalarda -sizi tanıştırayım- cümlesinde geçen istek ekinin ne anlama geldiği ve kuralının nasıl kullanıldığını ilk derste öğrenmek için ısrarcı olmuşlardı. Aynı zamanda aynı ünitede dinleme kısmına alınan "Güle Güle Sana" şarkısı çok uzun olmasına rağmen öğrenilen kural ile ilgili sadece iki cümle içermekteydi. Dinletilen metinlerin öğrencilerin seviyesine uygun kelimelerden oluşturulmamış olması kaynaklar konusunda yaşadığım en önemli sorundu. A1 seviyesinde ilk konulardan itibaren iyelik ekleri ve isim tamlamalarını içeren cümleler bulunuyor. $\mathrm{Bu}$ durum dinleme metinlerinde de aynı şekilde devam ettirilmekte. Ancak isim tamlamaları 5. ünitede yer alıyor. İsim tamlamaları verilmediği için tamlama şeklinde geçen kelimelere anlam verilemiyor. A1 seviyesinde 5. Ünitede isim-fiillerin geçtiği dinleme metni bulunuyor. A2 seviyesi 1. ünitede "Peronda" adlı dinlemede 'yerleştirdim' şeklinde kullanılan fiiller bulunuyor." diyerek konunun önemini gözler önüne sermiştir.

Gerek ana dili eğitimi öğretiminde gerek de Türkçenin yabancı dil olarak öğretiminde İstanbul Türkçesi ile konuşmak, yerel ağız özelliklerini derslerde kullanmamak büyük önem arz etmektedir. Ö.13 "Yabancılara Türkçe öğretimi için görevlendirilen bazı hocaların İstanbul Türkçesi yerine yöresel ağız özellikleriyle konuşmaları nedeniyle bazı öğrenciler, dinlediklerini anlamadıklarını ifade ediyorlardı. Sertifikasını almak isteyen bir öğrencim normalde çok iyi Türkçe bildiği hâlde yine İstanbul Türkçesi konuşmayan biriyle görüştükten sonra benden yardım isteyip "Hocam o hangi dili konuşuyor, ben o dili bilmiyorum. Eğer siz onun konuştuğu dili biliyorsanız bana yardım eder misiniz?" demişti." diyerek konunun önemini dile getirmiştir. 
Tablo 3.

Dinleme Eğitimindeki Sorunlara Yönelik Çözüm Önerileri

\begin{tabular}{lcc}
\hline Cevaplar & f & $\%$ \\
\hline $\begin{array}{l}\text { Dinleme eğitimi için gerekli teknik cihazlar ve ses kayıtları sağlanmalı } \\
\text { Dinleme metinlerinin kur düzeyinde ayarlanması, daha yavaş seslendirilmesi ve dinleme ders }\end{array}$ & 8 & 44 \\
saatinin artırılması & 5 & 27 \\
$\begin{array}{l}\text { Dinleme metinleri görsel destekli videolar şeklinde olmalı } \\
\text { Türk Edebiyatı metinleri, güncel ilgi çekici, günlük yaşama uygun }\end{array}$ & 3 & 16 \\
metinler seviyeye uygun olarak seslendirilmeli & 3 & 16 \\
Türk kültürünü, yaşayışını, şehirlerini anlatan, tanıtan düzeye & 3 \\
$\begin{array}{l}\text { uygun görsel ve işitsel videolar hazırlanmalı } \\
\text { Dinleme metinleri ilgili kurdaki dil bilgisi yapıllarını içerir }\end{array}$ & 16 \\
$\begin{array}{l}\text { şekilde seviyeye göre hazırlanmalıdır. } \\
\text { Türkçe alt yazılı filmlerden kesitler ya da çizgi filmler seviyeye göre } \\
\text { hazırlanmalı }\end{array}$ & 3 \\
\hline
\end{tabular}

Öğretim elemanları, dinleme eğitimi sürecinde yaşanan sorunlara yönelik 'dinleme eğitimi için gerekli teknik cihazlar sağlanmalı (\%44)', 'dinleme metinleri kur düzeyinde ayarlanmalı, daha yavaş seslendirilmesi ve dinleme ders saati artırılmalı (\%27)', 'dinleme metinleri görsel destekli videolar şeklinde olmalı (\%16)', 'Türk edebiyatı metinleri, güncel ilgi çekici, günlük yaşama uygun metinler seviyeye uygun olarak seslendirilmeli (\%16)', 'Türk kültürünü, yaşayışını, şehirlerini anlatan, tanıtan düzeye uygun görsel ve işitsel videolar hazırlanmalı (\%16)', 'dinleme metinleri ilgili kurdaki dil bilgisi yapılarını içerir şekilde seviyeye göre hazırlanmalı (\%16)' ve 'Türkçe alt yazılı filmlerden kesitler ya da çizgi filmler seviyeye göre hazırlanmalı (\%11)’ önerilerini getirmişlerdir.

Türkçenin yabancı dil olarak öğretiminde dinleme eğitiminde yaşanan sorunların bertaraf edilmesi için öğretim elemanlarının önerilerinin özellikle teknik imkânsızlıkların giderilmesi noktasında birleştiği görülmektedir. Ö. 12 bu konuda "Yabancı dil eğitimin iki yolu vardır. Ya öğrenciyi hayata götüreceksin ya da hayatı sınıfa getireceksin. Öğrenciyi, Türkiye'ye götüremediğime göre Türkiye'yi sınıfa getirmek gerekir. Bu da teknik destek ile mümkündür." diyerek düşüncelerini dile getirmiştir.

Ö. 13 dinleme metinlerinin hızlı seslendirilmesi sorununa yönelik çözüm olabilecek örnek bir uygulamadan söz etmiştir. "Bir gün yazar Sevinç Çokum'dan öğrencilerime izletmek için bir video yollamasını rica ettim. $\mathrm{O}$ da beni kırmayıp bir video gönderdi. Öğrenciler bu videoyu izlediklerinde çok heyecanlanıp "Hocam çok güzel konuşuyor. Dinlediğimiz her kelimeyi anladık. Yavaş ve kelimeleri çok net söylüyor." demişlerdi." $\mathrm{Bu}$ veriler 1şığında, Türk dizilerinin tüm dünyada bilinirliğinin arttığı günümüzde özellikle tanınan oyunculara bu uygulamada olduğu gibi videolar hazırlatılması dinleme eğitiminde yaşanan sorunların çözümünde bir katkı olarak düşünülebilir.

Ö.4. "Önce eğitici, öğrencilerine kulak terbiyesi vermeli. Öğrenci dinleye dinleye yavaş yavaş konuşmaya başlar. Öğrenci gramere boğulmamalı. Eğitici, her daim öğrencinin merakını kamçılamalı. Tabi bu durumda öğrencinin dile hem okulda hem de okul dışında maruz kalması gerek. Türkiye'de bu kolaydır. Yurt dışında ise çok zordur. Ne yapacak eğitici, öğrenciye onu çok da boğmayacak 
ödevler vermeli. Bir de yabancılar bizim dizileri çok seviyorlar. Eve gittiklerinde sevdikleri bir filmi izlemelerini ve filmi özetleyen bir ödev hazırlamalarını isteyin. Benim Alman öğrencilerim de yemeklerimizi severdi. Ben de ödev olarak onlara en çok sevdiğiniz yemeğimiz hangisi ise onun yapılışı ile alakalı bir ödev yapın derdim." diyerek dinleme eğitimi sürecine yönelik tecrübeleri ışı̆̆ında tavsiyelerde bulunmuştur.

Tablo 4.

Konuşma Ĕ̈itiminde Karşılaşılan Sorunlar

\begin{tabular}{lcc}
\hline Cevaplar & $\mathrm{f}$ & $\%$ \\
\hline Kendi dillerinde olmayan seslerin seslendirilmesi zorluğu & 16 & 88 \\
(özellikle g, ğ, 1, i, u, ü, o, ö, p sesleri) & 13 & 72 \\
Akııı konuşma yetersizliği & 13 & 72 \\
Özyeterlik algısı eksikliğine bağlı çekinme, konuşma kaygısı & 11 & 61 \\
Söz varlığının sınırlı olması, çeşitlilik/alan yoksunluğu & \\
Kitaplarda konuşma metinlerinin azlığı, güncel olmaması, doğrudan konuşmaya yönelik & 9 \\
kaynak bulunmaması, öğretilen dil bilgisi konusu ile ilişkisinin olmaması & 50 \\
Konuşmaya karşı ilgisizlik & 6 & 33 \\
Gramer kurallarını konuşma sürecine yansıtamama & 4 & 22 \\
Vurgu ve tonlamada yaşanan zorluklar & 3 \\
Sınıflarda öğrenci sayısının fazlalığı & 16 \\
Derse devam sorunu & 2 & 11 \\
\hline
\end{tabular}

Türkçenin yabancı dil olarak yurt dışında öğretiminde konuşma eğitimi sürecinde 'öğrencilerin kendi dillerinde olmayan sesleri (özellikle g, ̆g, 1, i, u, ü, o, ö, p sesleri) telaffuz ederken zorlanması (\%88)', 'akıcı konuşma yetersizliği (\%72)', 'özyeterlik algısı eksikliğine bağlı çekinme, konuşma kaygısı (\%72)', 'söz varlığının sınırlı olması, çeşitlilik/alan yoksunluğu (\%61)', 'kitaplarda konuşma metinlerinin azlığı, güncel olmaması, doğrudan konuşmaya yönelik kaynak bulunmaması, öğretilen dil bilgisi konusu ile metnin ilişkisinin olmaması (\%50)', 'konuşmaya karşı ilgisizlik'(\% 33)', 'gramer kurallarını konuşma sürecine yansıtamama (\%22)', 'vurgu ve tonlamada yaşanan zorluklar (\%16)', 'sınıflarda öğrenci sayısının fazlalığı' (\%11)' ve 'derse devam sorunu (\%11)' başlıklarında sorunların toplandığı görülmektedir.

Tablo 3'e bakıldığında konuşma eğitimi sürecinde yaşanan en büyük sorunun yabancı dil olarak Türkçe öğrenen öğrencilerin kendi dillerinde olmayan sesleri seslendirmede yaşadıkları zorluk olduğu görülmektedir. Bu konuyu Ö.2. "Sesli harflerin telaffuzunda zorluklar yaşanlyor. Özellikle l sesi. Daha ince okuma temayülü var” şeklinde, Ö.1. “ Ö̆grencilerin bazı heceleri Ingilizce telaffuza göre seslendirdikleri görülebilmektedir. Telaffuzunda en çok sorun yaşanan sesler ise $\imath, i$, u, ü, o ve ö'dür." şeklinde dile getirmiştir.

Konuşma eğitimi sürecinde eğitimin duyuşsal boyutunda görülen bir diğer sorun oldukça dikkat çekicidir. Öğrencilerin özyeterlilik algılarının düşük olması, konuşma kaygısı ve korkusu yaşamaları, öğrencileri konuşmaktan alıkoymaktadır. Ö.5 "Öğrencilere genel olarak konuşma etkinliği yaptırmak zor olmaktadır. Özellikle yaşı büyük ögrrencilerimizi sınıfta konuşturmakta zorluk yaşamaktayım. Yanlış konuşma kaygısı, konuşamama düşüncesi ve kelimeleri yanlış telaffuz etme 
endişesi öğrencileri konuşma etkinliğini yapmakta zorlamaktadır." diyerek bu duruma açıklık getirmiştir.

Öğretim elemanlarının ifade ettiği sorunlar içerisinde dikkat çeken bir diğer konu da akıcı konuşma yetersizliğidir. Ö.11. söz konusu sorunu "Akıcılık konusunda çok sorun var çünkü kelime bilgisi yeterli olmayınca durakslyorlar." diyerek Ö. 6. ise “ Öğrencilerin farklı alanlara ait terim bilgileri zayıftır. Bu da konu çeşitliliğini ve akıcı konuşmayı olumsuz yönde etkilemektedir.” diyerek ifade etmişlerdir.

Tablo 5.

Konuşma Eğitimindeki Sorunlara Yönelik Çözüm Önerileri

\begin{tabular}{lcc}
\hline Cevaplar & f & $\%$ \\
\hline Konuşma konuları öğrenci ilgisine göre belirlenmeli, konu çeşitliliği sağlanmalı & 10 & 55 \\
Ders kitaplarında konuşma metinleri artırılmalı, kitaplardaki konular ve etkinlikler gözden & 8 & 44 \\
geçirilmeli, konuşma eğitimine yönelik kaynak kitaplar, örnek konuşma videoları olmalı & & \\
Türkçe öğretecek öğretmenlerin seçimi dikkatle gerçekleştirilmeli, öğretim elemanlarının ana & 4 & 22 \\
dili Türkçe olmalı & 3 & 16 \\
Öğrenci-öğretmen iletişimi yakınlık içermeli, uygun geribildirim verilmeli & 2 & 11 \\
Konuşma ders saatleri artırılmalı & 2 & 11 \\
Sınıftaki öğrenci sayıları uygun şekilde olmalı & 2 & 11 \\
Kelime öğretimine önem verilmeli & 2 & 11 \\
Drama, tiyatro, şiir etkinliklerine yer verilmeli & 2 & 11 \\
Öğrencilerin derse devamı sağlanmalı & 1 \\
Eğiticiler için yönlendirici kaynak kitaplar hazırlanmalı & 5 \\
Dinleme becerisi ve konuşma becerisi birbirini desteklemeli & 1 & 5 \\
\hline
\end{tabular}

Konuşma eğitimi sürecinde daha etkili bir öğretim yapılabilmesi için 'konuşma konuları öğrenci ilgisine göre belirlenmeli, konu çeşitliliği sağlanmalı (\%55)', 'ders kitaplarında konuşma metinleri artırılmalı, kitaplardaki konular ve etkinlikler gözden geçirilmeli, konuşma eğitimine yönelik kaynak kitaplar, örnek konuşma videoları olmalı (\%44)', 'Türkçe öğretecek öğretmenlerin seçimi dikkatle gerçekleştirilmeli, öğretim elemanlarının ana dili Türkçe olmalı (\%22)', 'öğrenci-öğretmen iletişimi yakınlık içermeli, uygun geribildirim verilmeli (\%16)', 'konuşma ders saatleri artırılmalı (\%11)', 'sınıftaki öğrenci sayıları uygun şekilde olmalı (\%11)', 'kelime öğretimine önem verilmeli (\%11)', 'drama, tiyatro, şiir etkinliklerine yer verilmeli (\%11)', 'öğrencilerin derse devamı sağlanmalı (\%11)', 'eğiticiler için yönlendirici kaynak kitaplar hazırlanmalı (\%5)' ve 'dinleme becerisi ve konuşma becerisi birbirini desteklemeli (\%5)’ önerileri getirilmiştir.

Ö. 5 ve Ö. 6 sırası ile öğretim elemanlarının konuşma eğitimindeki sorunlara çözüm olarak en fazla mutabık oldukları konuları "Her alanda olduğu gibi bu alana ilişkin kaynak çalışması yapılmalıdır. Öğretmenlerin hâlihazırda hemen kullanabilmesi için bir konuşma kitabı çıkarılabilir. Bunun haricinde öğrencilerin ilgisini çekecek oyunların ve konuşma etkinliklerinin olduğu bir çalışma yapılabilir.”; "Öğrencilerin ilgilerini çekecek konuşma konular seçilmeli ve ögrenciye her şeyden önce konuşmak için motive edici cümleler söylenmeli, motivasyon artırıcı davranışlarda bulunulmalıdır. " şeklinde dile getirmişlerdir.

Ö. 6 dil eğitiminin dört temel dil becerisinin birbirini destekler şekilde verilmesi gerektiğini "Doğru ve akıcı konuşmanın gerçekleşmesi için özellikle dinleme 
becerisinin iyi kazandırılmış olması gerekmektedir. Kelime bilgisi de çok büyük önem taşımaktadır. Tarih, coğrafya, felsefe, fizik, mühendislik, tıp, bankacilık, mimarlık, güzel sanatlar, spor $v b$. birçok alana ait diyaloglar sinıf ortamına taşınmalı, her alanda bilgi paylaşımında bulunulmalıdır. " diyerek dile getirmiştir.

Ö.2 eğitimde öğretmen rolünün mutlak önemine değinmiş ve "Bence gençlik dünyanın her yerinde aynı gençlik. İğneyi kendimize hesabı yaparak şöyle diyorum: Yabancılara Türkçe ögreten hocaların da seçimi son derece önemli. Sadece bilimsel çalışma yapmış ama ufkunu açamamış, teknolojiyi takip edememiş hocayla da bu işler zor. Çünkü bu hocalarımızın da maalesef farklı bakış açıları olmadı̆̆ için ögrencinin de ufkunu açamıyorlar." ifadeleriyle konuşma eğitiminde sorunları çözebilme yolunda önemli bir noktaya değinmiştir. Ö.13 de "Normalde çok neşeli bir erkek ögrencim sınavda yanlış bir kelime kullandıktan sonra aşırı heyecanlanıp ă̆lamaya başlamıştı. Bunun gibi durumlarda öğrencinin rahatlaması, sınav kaygısını bırakıp konuşmaya devam edebilmesi için ögretmenin olumlu bir yaklaşım sergilemesi gerekiyor." diyerek duyuşsal alanda sorunun çözümü noktasında öğretmenin rolüne parmak basmıştır.

Tablo 6.

Okuma Eğitiminde Karşılaşılan Sorunlar

\begin{tabular}{|c|c|c|}
\hline Cevaplar & $\mathrm{f}$ & $\%$ \\
\hline Sesli okuma sürecinde telaffuz, vurgu, tonlama hataları & 15 & 83 \\
\hline Ders kitabı haricinde okuma metni bulunmaması & 9 & 50 \\
\hline Okuma kaygısı, motivasyon eksikliği & 9 & 50 \\
\hline $\begin{array}{l}\text { Seviyeye uygun okuma metni bulma sıkıntısı, mevcut kitaplarda yer alan metinlerin uzun } \\
\text { olması, dil bilgisi konularıyla bağdaşmaması, etkinliklerin seviye üzerinde olması }\end{array}$ & 7 & 38 \\
\hline Söz varlığı yetersizliği & 5 & 27 \\
\hline $\begin{array}{l}\text { Okuduğunu anlama güçlüğü, deyimler ve atasözlerinin bulunduğu metinlerin güç } \\
\text { anlaşılması }\end{array}$ & 3 & 16 \\
\hline Öğrenci sayısının sınıflarda fazla olması & 1 & 5 \\
\hline Sözlük kullanma alışkanlığının olmaması & 1 & 5 \\
\hline
\end{tabular}

Türkçenin yabancı dil olarak yurt dışında öğretimi sürecinde okuma eğitiminde; 'sesli okuma sürecinde telaffuz, vurgu, tonlama hataları (\%83)', 'ders kitab1 haricinde okuma metni bulunmaması (\%50)', 'okuma kaygısı, motivasyon eksikliği (\%50)', seviyeye uygun okuma metni bulma sıkıntısı, mevcut kitaplarda yer alan metinlerin uzun olması, metinlerin dil bilgisi konularıyla bağdaşmaması, etkinliklerin seviye üzerinde olması (\%38)', 'söz varlığı yetersizliği (\%27)', 'okuduğunu anlama güçlüğü, deyimler ve atasözlerinin bulunduğu metinlerin güç anlaşılması (\%16)', 'öğrenci sayısının sınıflarda fazla olması (\%5)' ve 'sözlük kullanma alışkanlığının olmaması (\%5)' başlıklarında sorunlarla karşılaşıldığı görülmektedir.

Okuma eğitiminde metinler temel araçlardandır. Eğitim sürecinde uygun metin bulma sıkıntısı, kitap sıkıntısı, metinlerin seviyenin üzerinde olabilmesi, öğretilecek dil bilgisi konusu ile ünitede verilen metin arasında ilişki bulunmayışı gibi sorunlar bulunduğunu belirten Ö.13 "Örneğin A2 seviyesinde borsa ile ilgili bir metin var ki bu metinde geçen kelimelerin ne anlama geldiğini ya da borsada yapılan o işlemlerin neler olduğunu kendim bile bilmiyorum. Bunu çocuklara nasıl anlatabilirim ki? Bl ve daha üst seviyelerdeki metinlerde yer alan etkinlikler 
ögrencilerin seviyelerinin çok üstünde. Öğrencinin öğretmenin yardımı olmadan bunları yapmasının mümkün olmadığını düşünüyorum." diyerek okuma eğitiminde düzeye uygun metin ve etkinlik kullanmanın önemine değinmiştir. Ö. 12 de aynı sorunu "Örneğin, Al kitabında mahallemizin adı Çamlıca Mahallesi. Çocuğa mahalleyi anlatıyorum. Sonra Çamlıca Mahallesi nerede? Yeni Mahallede. Bu büyük bir anlam karmaşass yaratıyor. Kitaplardaki tüm metinlerin bu bağlamda kontrol edilmesi gerektiğini düşünüyorum. ” şeklinde dile getirmiştir.

Okuma eğitiminin duyuşsal boyutunda yer alan durumların da yüzde elli oranında sorun olarak belirtildiği görülmektedir. Ö. 15 bu durumu "Okuma metnini okurken yeterli cesarete sahip olamayabiliyorlar" şeklinde; Ö. 1 ise "Öğrencileri ders dişı okumalara yönlendirmek ve motive etmek konusunda zorluklar yaşanmaktadır. Bunun birçok sebebi olmakla birlikte en belirgini eğitime ders ve sinav geçme açısından yaklaşmaları ve bunu düşük puanlarla da olsa başaracaklarını bilmeleridir. ” şeklinde ifade etmiştir.

Tablo 7.

Okuma Eğitimindeki Sorunlara Yönelik Çözüm Önerileri

\begin{tabular}{lcc}
\hline Cevaplar & f & $\mathbf{\%}$ \\
\hline $\begin{array}{l}\text { Öğrenci düzeyine uygun okuma kitapları yazılmalı } \\
\text { Program, müfredat, kitaplar gözden geçirilmeli, seviyeye uygun hâle getirilmeli, kitaplar }\end{array}$ & 44 \\
yaşama uygun ve işlevsel olmalı & 7 & 38 \\
Sesli okumada vurgu, tonlama ve telaffuza dikkat edilmelidir & 4 & 22 \\
Sınıflardaki öğrenci sayıları az olmalı, ders saati artırılmalı & 2 & 11 \\
Öğretmenler öğrencilerini teşvik edecek şekilde davranmalı (Uygun geribildirim, ödül vb.) & 2 & 11 \\
Öğrenciler sözlük kullanma alışkanlığı edinmeli, söz varlıkları artırılmalı & 1 & 5 \\
Metinler öğretim elemanları tarafindan temin edilmeli & 1 & 5 \\
Dünya masalları yabancı öğrencilere göre hazırlanmalı & 1 & 5 \\
Tüm dinlerde ortak olan kıssalar yabancı öğrenciler için kitaplaştırılmalı & 1 & 5 \\
Başka ülkelerin kültür ve tarih ögelerine yer veren metinler de hazırlanmalı & 1 & 5 \\
\hline
\end{tabular}

Öğretim elemanları; 'öğrenci düzeyine uygun okuma kitapları yazılmalı (\%44)', 'program, müfredat, kitaplar gözden geçirilmeli, seviyeye uygun hâle getirilmeli, kitaplar yaşama uygun işlevsel olmalı (\%38)', 'sesli okumada vurgu, tonlama ve telaffuza dikkat edilmeli (\%22)', 'sınıflardaki öğrenci sayıları az olmalı, ders saati artırılmalı (\%11)', 'öğretmenler öğrencilerini teşvik edecek şekilde davranmalı (\%11)', 'öğrenciler sözlük kullanma alışkanlığı edinmeli, söz varlıkları artırılmalı $(\% 5)$ ', 'metinler öğretim elemanları tarafindan temin edilmeli (\%5)', 'dünya masalları yabancı öğrencilere göre hazırlanmalı (\%5)', 'tüm dinlerde ortak olan kıssalar yabancı öğrenciler için kitaplaştırılmalı (\%5)' ve 'başka ülkelerin kültür ve tarih ögelerine yer veren metinler hazırlanmalı (\%5)’ önerilerini okuma eğitimindeki sorunların çözümü için sunmuşlardır.

Ö. 12 kitaplarda yer alan metinlerin hazırlanmasına yönelik olarak "Kitaplarda okuma metinlerinde öncelik sırasına dikkat edilmeli. Sonradan ögretilecek konular öne alınmış. Özel konuları içeren metinlerden ziyade bütün dünya vatandaşlarını ilgilendiren hususlarını öncelikle kitaplarda ele alınmast gerekir." önerisinde bulunmuştur. Ö.15 öğretim elemanlarının çoğunluğu tarafından ifade edilen ders kitabı dışında okuma kaynağı yokluğu sorununu "Seviyeye göre okuma hikâyeleri konusunda zorluk yaşamaktayız. Bunların temin edilmesi yararlı olur.” şeklinde dile 
getirmiş ve bu önerisine okuma eğitimi için "Telaffuz çalışmalarına ă̆ırlık verilmeli, kelime dağarcıklarını zenginleştirici etkinliklerde bulunulmalıdır." önerisini eklemiştir.

Öğretim elemanlarının büyük çoğunluğu ders kitabındaki metinlerin iyileştirilmesine, bu metinlere ek olarak öğrenci düzeyine uygun okuma kitaplarının hazırlanmasına yönelik çözüm önerileri sunmuşlardır. Ö.17 bu konuda "Kitaba bağıml kalmayarak metinlerin ögretim elemanı tarafindan temini yapılmalı. Ögrenci ilgisi tespit edilmeli (ihtiyaç analizi) ilgi alanlarına yönelik metinlerin okutulması ile okuma ilgisi artırılabilir. Okuma ilgisi artırıldıktan sonra farklı metinlere yönelinebilir." demek suretiyle konuya farklı bir çözüm önerisi getirmiştir. Ö.18 okuma eğitimine yönelik projeleri olduğunun altını çizerek "Tüm dünyanın ortak malı olan masallar yabancı ögrenciler için kitaplaştırılmalı, tüm dinlerde ortaklı̆̆ olan kissalar yabancı öğrenciler için kitaplaştırılmall, sadece kendi kültürel ögelerimizle ilgili metin çalışmalart yapılmamall, başka ülkelerin kültür ve tarih ögelerinden de metin çalışması yapılmalıdır." önerilerinde bulunmuştur.

Tablo 8.

Yazma Ĕgitiminde Karşılaşılan Sorunlar

\begin{tabular}{lcc}
\hline Cevaplar & f & $\%$ \\
\hline Yazma özyeterliliği düşüklüğ̈̈, yazma kaygısı, ilgisizlik, olumsuz tutum & 13 & 72 \\
Dil bilgisi hatalarının sık sık tekrar edilmesi & 11 & 61 \\
Alfabe farklılığı, seslere hâkim olamama & 7 & 38 \\
Çok heceli sözcüklerde sesleri karıştırma, "b, d; c, ç; i, 1; o, ö; u, ü” seslerinin karıştırılması & 7 & 38 \\
Söz varlı̆̆ı sınırlılığı & 5 & 27 \\
Ders kitaplarında yazma etkinliklerinin hayatın içinden olmayışı, aynı konuların tekrar & 4 & 22 \\
etmesi, yönergelerin açık olmaması & 4 & 22 \\
Cümle diziminde yapılan yanlışlıklar & 3 & 16 \\
Büyük-küçük harf kuralına uymama & 3 & 16 \\
Noktalama işareti yanlışlıkları & 3 \\
\hline
\end{tabular}

Türkçenin yabancı dil olarak yurt dışında öğretiminde yazma eğitimine yönelik 'yazma özyeterliği düşüklüğü, yazma kaygısı, ilgisizlik, olumsuz tutum (\%72)', 'dil bilgisi hatalarının sık sık tekrar edilmesi (\%61)', 'alfabe farklılığı, seslere hâkim olamama (\%38)', 'çok heceli sözcüklerde sesleri karıştırma, (b, d/ c, ç/ i, 1/ o, ö/ u, ü) (\%38)', 'söz varlığı sınırlılığı (\%27)', 'ders kitaplarında yazma etkinliklerinin hayatın içinden olmayışı, aynı konuların tekrar etmesi, yönergelerin açık olmaması (\%22)', 'cümle diziminde yapılan yanlışlıklar (\%22)', 'büyük-küçük harf kuralına uymama (\%16)' ve 'noktalama işareti yanlışlıkları (\%16)' sorunlarının bulunduğu ifade edilmiştir.

Yazma eğitimi sürecinde öğretim elemanları özellikle öğrenmenin duyuşsal boyutunda yer alan kaygı kavramına dikkat çekmişlerdir. Ö. 13 "Öğrenciler diğer becerilerle kıyaslandı̆̆ında en çok yazma becerisinde kayglanmaktadır.” Ö. 12 de "Yazmaya karşı ilgileri var ama konuşma ve dinlemede olan kaygı özellikle yazma ĕgitiminde daha baskın hissediliyor.” Ö. 7 "Yazmak dinlemek ya da konuşmak kadar eğlenceli olmadiğı için fazla kural olduğu için elbet motivasyon sürekli zirvede olmuyor ve yanlış yazacă̆ım kaygısını çok yaşıyorlar." Ö. 15 "Seslerin ve eklerin yazımında hata yaptıklarında motivasyonlar düşebilmektedir. Bu durumda 
ödev yapmak istemeyebiliyorlar." diyerek bu durumu dile getirmişlerdir. Yazma eğitimi sürecinde dikkati çeken bir diğer sorun ise alfabe farklılıklarından kaynaklanan sorunlardır. Ö. 2 "Arap alfabesinden Latin alfabesine geçişte harfleri düzgün yazmak ve hizalamayı ögrenmek ögrencileri en fazla zorlayan durumdur." diyerek bu konuyu dile getirmiştir. Yazma becerisine yönelik Ö. 4 "En zor beceri." Ö. 5 "Öğrenciler diğer alanlara göre yazmada daha fazla zorluklar yaşamaktadırlar." demişler ve yabancı dilde yazma becerisinin diğer becerilere oranla daha zor bir beceri alanı olduğuna dikkat çekmişlerdir.

Dil bilgisi kurallarının öğrenciler tarafindan tam olarak kavranmadığ1 durumlarda da yazma eğitiminde sorunlar yaşandığı öğretim elemanları tarafindan belirtilmiştir. Ö.1 "Yazma eğitiminde en çok karşılaşılan hata söz dizimsel hatalardır. Öğrenciler cümle kurarlarken ana dillerinin ve bildikleri başka bir yabancı dilin söz dizimini Türkçeye aktarmaktadırlar. Bu, yazdıkları metinde devrik cümlelerin sayısının artmasına sebep olmaktadır." diyerek önceki öğrenmelerin ileriye ket vurma durumunu görünür k1lmıştır. Ö. 15 de "Eklerin ve ünlülerin yazımı konusunda büyük problemler yaşanmaktadır." diyerek aynı konuya değinmiştir. Ö.16 "Yazma becerisi zaten güç geliştirilen bir beceridir. En çok yaşadı̆̆ım husus ögrencilerin ana dillerinde olduğu gibi bağlaçlarla birbirlerine bağlanmış uzun cümleler yazmak istemesiydi. Açı, net, kısa ve anlaşılır cümle yazmaları için her seferinde uyarmak gerekiyordu. Onun yanı stra imla meselesi bir diğer sorundu. Türkçede kulağa göre imla varken Arap dilinde göze göre imla vardır. Dolaylsıyla ögrenci Türkçe imlayı daha önce ögrendiği İngilizce imla sistematiğine göre yazma eğilimindedir." diyerek yine yazma becerisinin zor bir beceri alanı olduğuna, ileriye ket vurmaya ve dil bilgisi sorunlarına atıfta bulunmuştur.

Tablo 9.

Yazma Eğitimindeki Sorunlara Yönelik Çözüm Önerileri

\begin{tabular}{llc}
\hline Cevaplar & $\mathrm{f}$ & $\%$ \\
\hline İlgi duydukları konuda daha fazla yazı yazdırılmalı & 8 & 44 \\
Uygun geribildirim verme, öğrencilerin yazdıklarını sürekli & 7 & 38 \\
kontrol etme & 6 & 33 \\
Yazma eğitimine yönelik kaynak kitap oluşturulmalı & 5 & 27 \\
Süreç temelli yazma eğitimi verilmeli & 3 & 16 \\
Ders kitaplarındaki yazma konuları hayatın içinden olmalı & 3 & 16 \\
Yazma eğitimini desteklemek için kitap okuma oranını artırma & 2 & 11 \\
Akran dönütü & 2 & 11 \\
Sözlük kullanma alışkanlığı kazandırılmalı, söz varlıkları artırılmalı & 2 & 11 \\
Dikte çalışmalarına fazla yer verilmeli & 2 & 11 \\
Yazma etkinlikleri sanal ortama da taşınmalı, portfolyo uygulaması yapılmalı &
\end{tabular}

Yazma eğitimi sürecinde yaşanan sorunlara yönelik 'öğrencilerin ilgi duydukları konuda daha fazla yazı yazdırılmalı (\%44)', 'uygun geribildirim verilmeli, öğrencilerin yazdıkları sürekli kontrol edilmeli (\%38)', 'yazma eğitimine yönelik kaynak kitap oluşturulmalı (\%33)', 'süreç temelli yazma eğitimi verilmeli (\%27)', 'ders kitaplarındaki yazma konuları hayatın içinden olmalı (\%16)', 'yazma eğitimini desteklemek için öğrencilerin kitap okuma oranı artırılmalı (\%11)', 'dikte çalışmalarına fazla yer verilmeli (\%11)' ve 'yazma etkinlikleri sanal ortama da taşınmalı, portfolyo uygulaması yapılmalı (\%11)’ önerileri getirilmiştir. 
Yabancı bir dilde yazma edimi gerçekleştirecek bireylerin o dile ilişkin sesleri, kelimeleri, cümle kuruluşlarını, dil bilgisi yapılarını bilmesi gerekmektedir. $\mathrm{Bu}$ süreçte yaşanan sorunların çözümü noktasında Ö. 2 "Sözlük kullanma alışkanlığının kazandırılması lazım. Kelime hazineleri çeşitli oyunlarla keyifli hâle getirilebilir." diyerek kelime bilgisinin önemine Ö. 3 de "Sinıfta tahtaya yazmak için kalkan ögrenciyle beraber tüm ögrencilerin yazması, doğrunun ve yanlışın aynı anda görülmesi, konuşulması gerekmektedir." Ö. 5 "Yazma etkinliği için konu çeşitliliği artırllpp ögrencilerin istediği konuyu seçerek yazma ĕgitimi verilmesi sorunlart azaltabilir." diyerek süreç temelli yazma eğitiminin ve uygun geri bildirimin önemine değinmişlerdir. Ö.1 dil eğitiminde dört temel dil becerisinin birbirini destekler şekilde verilmesi gerektiğini "Dil eğitiminde dört temel becerinin gelişmesinin birbirine doğru orantryla bağll olduğu göz önünde bulundurularak öğrencilere okuma alışkanlığı kazandırılmalıdır. Buna paralel olarak sözcük dağarcıklarının geliştirilmesine yönelik etkinlikler yapılmalıdır. Öğrencilerin Türkçe söz dizimi kurallarını iyi bir şekilde kavramaları ve içselleştirmeleri sağlanmalıdır." diyerek çözüm önerisinde bulunmuştur. Ö. 17 yazma eğitiminde karşılaşılan sorunların çözümü için "Yazma etkinliklerinin sınıfla sinırlandırılmaması, alfabe farklılıklarl ve ortaklıkları üzerinde durulması, yazma etkinliklerinin sanal ortama da taşınması"; Ö.18 "Yazmadan sonra ögrenciye dönüt verilmeli, bir ögrencinin kâğılı projeksiyonla yansıtılarak tahlil yapılmalıdır. Böylece diğer ögrencilerin de aynı hataları yapmalarını engellemek mümkün olacaktır. " önerilerini sunmuştur.

Tablo 10.

Dil Bilgisi Öğretiminde Karşılaşıllan Sorunlar

\begin{tabular}{lcc}
\hline Cevaplar & $\mathrm{f}$ & $\%$ \\
\hline Önceden öğrenilen yabancı dil konularının ya da ana dilin ileriye ket vurması & 8 & 44 \\
Öğrencilerin olumsuz tutumu, motivasyon eksikliği, kaygı düzeyi yüksekliği & 7 & 38 \\
Dil bilgisi öğretimine yönelik kaynak eksikliği & 5 & 27 \\
Teknolojik araç gereçlerden eğitim sürecinde yararlanamama & 4 & 22 \\
Ders kitaplarında yer alan gramer konularının sıralaması, dil bilgisi kurallarının etkinliklere & 3 & 16 \\
yeteri kadar yerleştirilememesi & 2 & 11 \\
Ses olayları, fiilimsiler & 1 & 5 \\
Türkçeye maruz kalamama & \\
\hline
\end{tabular}

Dil bilgisi öğretimi sürecinde 'önceden öğrenilen yabancı dil konularının ya da ana dilin ileriye ket vurması $(\% 44)$ ', 'ögrencilerin olumsuz tutumu, motivasyon eksikliği, kaygı düzeyi yüksekliği (\%38)', 'dil bilgisi öğretimine yönelik kaynak eksikliği (\%27)', 'teknolojik araç-gereçlerden eğitim sürecinde yararlanamama (\%22)', 'ders kitaplarında yer alan gramer konularının sıralaması, dil bilgisi kurallarının etkinliklere yeteri kadar yerleştirilememesi (\%16)', 'ses olayları, fiilimsiler (\%11)' ve 'Türkçeye maruz kalamama (\%5)' sorunlarının bulunduğu tespit edilmiştir.

Türkçenin yabancı dil olarak öğretilmesi sürecinde dil bilgisi öğretimi konusunda öğretim elemanlarının büyük çoğunluğu öğrencilerin ana dillerinde ya da öğrendikleri başka bir dilde bulunan kuralların ileriye ket vurma yaparak dil bilgisi öğretimini zorlaştırdığını bildirmişlerdir. Ö.15 "Türkçenin ekli bir dil olması en önemli zorluktur. Genellikle farkl dil aile grubunda olan ana dile sahip 
ögrencilerim olduğu için Türkçenin yapısı onlara aykırı gelmektedir." diyerek dil bilgisinde yaşadığı sorunları ifade etmiştir.

Dil bilgisi öğretiminde tespit edilen sorunlar arasında ikinci sırada bulunan sorun, öğrenmenin duyuşsal boyutu ile ilgilidir. Ö. 1 "Türkçe dil bilgisinin zor olduğu önyargısının ögrencileri kayglya sevk etmesi”, Ö. 5. "Öğrenciler tutum olarak dil bilgisini, ögrenmesi güç bir beceri alanı olarak düşünmektedir.”, Ö. 2. "Öğrenciler konuşabilmek için dil bilgisi kurallarına hâkim olmak gerektiğini hâlâ idrak edememişler. Bilgi eksikliği yüzünden dil bilgisine mesafeli duruyorlar ve bu onları içinden çıkılamaz bir psikolojiye sürüklüyor" demişler ve bu sorunu sözleriyle görünür kılmışlardır.

Tablo 11.

Dil Bilgisi Öğretiminde Karşılaşılan Sorunlara Yönelik Çözüm Önerileri

\begin{tabular}{lcc}
\hline Cevaplar & $\mathrm{f}$ & $\%$ \\
\hline Dil bilgisi eğitimi dört temel dil becerisinin içerisinde sezdirilerek öğretilmeli & 7 & 38 \\
Öğretim elemanları kitaba bağlı kalmaksızın güncel hayatı içeren dil bilgisi etkinlikleri & \\
tasarlamalı, bulunduğu yörenin yerel, kültürel özellikleri işe koşulmalı, farklı yöntem ve & 5 & 27 \\
teknikler kullanılmalı & \\
Eğitim teknolojilerinden yararlanma imkânı sağlanmalı & 4 & 22 \\
Öğretime yönelik materyal temini, kaynakların Türkçenin dil yapısına uygun hazırlanması & 4 & 22 \\
\hline
\end{tabular}

Türkçenin yabancı dil olarak öğretilmesi sürecinde dil bilgisi eğitiminde karşılaşılan sorunlara yönelik olarak getirilen çözüm önerileri 'dil bilgisi eğitimi dört temel dil becerisinin içerisinde sezdirilerek öğretilmeli (\%38)', ‘öğretim elemanları kitaba bağlı kalmaksızın güncel hayatı içeren dil bilgisi etkinlikleri tasarlamalı, bulunduğu yörenin yerel, kültürel özellikleri işe koşulmalı, farklı yöntem ve teknikler kullanılmalı (\%27)', 'eğitim teknolojilerinden yararlanma imkânı sağlanmalı (\%22)' ve 'öğretime yönelik materyal temin edilmeli, kaynaklar Türkçenin dil yapısına uygun hazırlanmalı (\%22)’ şeklinde sıralanmaktadır.

Çağdaş dil öğretim yaklaşımları dil bilgisi öğretimini ayrı bir ders alanı olarak değil dil becerilerinin öğretimi sürecinde sezdirilerek öğretilmesini öngörmektedir. Yurt dışında Türkçe öğreten öğretim elemanları da öğretim tecrübeleri doğrultusunda bu konunun önemine değinmişlerdir. Ö.5 "Dil bilgisi ögretiminde ögrenciye doğrudan konunun adını vermeden önce örnekler kullanarak bunun üzerine konuşup kavramalarını sağlamaktayım. O konuya uygun taklit ve görselleri kullanarak örnekleri çoğaltarak doğrudan dil bilgisi verilmemesine dikkat etmekteyim. Daha sonra ögrenci durumu biraz kavrayınca konuyu anlatıp farklı kullanım alanlarını kullanım yerlerini anlatıp dil bilgisi kâğttları ile pekiştirmelerini sağlamaya çalışmaktayım." şeklinde bu durumu dile getirmiştir.

Ö. 6 ise öğretim sürecinde öğrenen özelliğini ve öğretim yapılan yerin özelliğini dikkate alma hususuna "Bireysel farklılıklar dikkate almak gerekmektedir. Derslerde farkl yöntem ve tekniklere yer verilmelidir. Görev yapılan coğrafyanın özellikleri bilinmeli, o bölgenin yaşam koşullarına uygun, ihtiyaca yönelik konu seçimi yapılmalıdır." diyerek değinmiştir.

Dil öğretimi, öğreticinin yaratıcı becerilerinin gelişmiş olması ile de yakından ilgilidir. Ö. 7 "Fiilimsiler özellikle de slfat fiilleri anlatırken bir tiyatrocu gibi canlandırmalar yapıyorum. Ögretmenlere tavsiyem gerekirse tiyatrocu gerekirse 
şarkıcı olmak hem öğretmemize yardımcı oluyor hem ögrencinin motivasyonunu artırıyor" diyerek öğretim elemanlarının farklı yöntem ve teknikleri kullanarak etkinlik tasarlayabilme becerisinin bulunması gerektiğine değinmiştir.

Tablo 12.

Türkçenin Yurt Dışında Öğretiminde Çalışılan Üniversitelerin Uygulamalarına Bağll Sorunlar

\begin{tabular}{lcc}
\hline Cevaplar & f & $\%$ \\
\hline Teknik destek, teknoloji yetersizliği & 11 & 61 \\
Ders programları & 9 & 50 \\
Ders saati yetersizliği & 7 & 38 \\
Dersliklerin fiziki yetersizliği (alan, ısınma, aydınlanma vb.) & 7 & 38 \\
Ülkelerde yaşanan siyasî sorunlar nedeniyle eğitimin kesintiye uğraması, tatillerin fazlalığı, & 6 & 33 \\
bürokratik işlemlerin uzun sürmesi & \\
Öğrenci ilgisizliği, motivasyon düşüklüğü, özgüven eksikliği, ders devamsızlığı & 27 \\
Kitap kullanımını kısıtlama, engelleme, defter, kalem yokluğu, eğitim materyali eksikliği & 4 & 22 \\
Ders kitabı dışında yeterli akademik ve yazınsal kaynağın çoğu bölümde olmaması & 4 & 22 \\
Öğrencilerin Türkiye'de yaşamadıkları için dile maruz kalamayışları & 4 & 22 \\
Öğretim elemanı yetersizliği & 3 \\
Öğretmenlerin mesleki yetersizliği & 16 \\
Öğretim tekniği yanlışlığı & 3 & 16 \\
Öğrenci seviyelerinin ilk girişten itibaren düşük olması & 2 & 11 \\
Yerel öğreticilerin Türkoloji’ye ve alana ilişkin formasyonunun zayıf olması & 2 & 11 \\
Türkiye'den gönderilen akademisyenlerin alana uzak olması & 1 & 5 \\
\hline
\end{tabular}

Türkçenin yurt dışında öğretiminde çalışılan üniversitelerin uygulamalarına bağglı sorunlar şu şekilde tespit edilmiştir: 'Teknik destek, teknoloji yetersizliği (\%61)', 'ders programları (\%50)', 'ders saati yetersizliği (\%38)', 'dersliklerin fiziki yetersizliği (\%38)', 'ülkelerde yaşanan siyasî sorunlar nedeniyle eğitimin kesintiye uğraması, tatillerin fazlalığı, bürokratik işlemlerin uzun sürmesi (\%33)', 'öğrenci ilgisizliği, motivasyon düşüklüğü, özgüven eksikliği, ders devamsızlığı (\%27)', 'kitap kullanımını kısıtlama, engelleme, defter, kalem yokluğu, eğitim materyali eksikliği $(\% 22)$ ', 'ders kitabı dışında yeterli akademik ve yazınsal kaynağın çoğu bölümde olmaması (\%22)', 'öğrencilerin Türkiye'de yaşamadıkları için dile maruz kalamayışları (\%22)', 'öğretim elemanı yetersizliği (\%16)', 'öğretmenlerin mesleki yetersizliği (\%16)', 'öğretim tekniği yanlışlı̆̆ $(\% 11)$ ', 'öğrenci seviyelerinin ilk girişten itibaren düşük olması $(\% 11)$ ', 'yerel öğreticilerin Türkoloji'ye ve alana ilişkin formasyonunun zayıf olması $(\% 5)$ ' ve 'Türkiye'den gönderilen akademisyenlerin alana uzak olması (\%5)'.

Ö. 13 yurt dişında en fazla yaşanan sorunu “Üniversitede TiKA'nın desteğiyle akıllı tahta, projeksiyon, bilgisayar ve diğer teknik araçlar sağlanmasına rağmen okul yönetiminin bunların çoğunu kilitli bir yerde tutması nedeniyle istediğimiz gibi kullanamadık. Kendi bilgisayarım ve hoparlörümü her gün götürüp getirmek zorunda kaldım." demek suretiyle dile getirmiştir.

Ö. 1 bir üniversitenin Türk Dili ve Edebiyatı Bölümünde görev yapmış ve burada yaşadı̆̆1 sorunlar1 "Bulunduğum ülkenin üniversitesinin ĕgitimi sistemleri, ders programlarının dil eğitimine uygun olmaması (lisans eğitiminin 3 yll olması, ders 
saatlerinin az olmasl, hazırlık eğitiminin olmaması vb.), Türkçe ögretimiyle ilgili hazırlanmış olan materyallere erişim, sınıfların fiziki koşullarının iyi olmaması ve teknolojik imkânların kisitlı olması, Türkoloji bölümlerinde öğrenci seviye ve niteliklerinde homojenliğin sağlanamaması" şeklinde özetlemiştir.

Ö. 14 ise yaşanan sorunları "Üniversitede bize ait sinıf yok. Programa göre boş olan sinıflar bize veriyorlar. Sinıflarda hiçbir teknolojik araç-gereç yok. Üniversitede kablolu ve kablosuz internet imkânı yok. Sinifların aydinlanma ve ısınma problemleri var. Demir sac ile çevrilerek oluşturulmuş sinıflar var. Bu sınıflarda sacdan duvar yapılmış ve duvar tavana ulaşmıyor. Yani tavandan aşağıya l'er metrelik boş alan var. Bu alan sınıfların ses yalıtımını engelliyor. Dışarıdan derse çok fazla ses geliyor. Siralarda da kırıklar var." diyerek dile getirmiştir.

Ö. 13 çalışmış olduğu üniversitede herhangi bir kitap kullanımına yönetimin izin vermediğini, ders hocasının materyalini kendisinin hazırlaması gerektiğini ifade ettikten sonra "Öğrencilere verdiğimiz metinlerin içeriğinde Türkiye'yi öne çıkaran şeylerin yer almamasi konusundaki uyarılar da dersin işlenişi sürecinde motivasyonumuzu düşürüyordu. Dilini ögrettiğimiz ülke ile ilgili kültürel unsurların bile metinlerde yer almasına karışılması dil öğretim sürecinde bana en çok sıkıntı yaratan durumlardl. Bu konular ile ilgili birçok defa Yunus Emre Kültür Merkezine ve üniversitedeki bölüm başkanlı̆̆ına şikâyetimi dile getirsem de herhangi bir çözüm bulunmadı̆̆ için süreci kitapsız ve yasaklarla dolu can sıkıcı bir şekilde sürdürmek zorunda kaldım." diyerek bulunduğu üniversitenin uygulamalarına bağlı yaşadığı sıkıntıları dile getirmiştir.

Ö. 3 temel sorunları "Yeni ögretim tekniklerinin bilinmemesi, ögrencinin aktif olduğu uygulama merkezli dil ögretiminin değil de ögretmen anlatımının tercih edildiğ bir ortam, setlerin seviyeye tam olarak uygun hazırlanmaması (genellikle seviye üstü) "' şeklinde üç temel başlıkta ifade etmiştir.

Tablo 13.

Üniversitelerin Uygulamalarına Bağlı Sorunlara Yönelik Çözüm Önerileri

\begin{tabular}{|c|c|c|}
\hline Cevaplar & $\mathrm{f}$ & $\%$ \\
\hline $\begin{array}{l}\text { Üniversiteler fiziki ve teknolojik imkâna kavuşturulmalı, teknik destek sağlanmalı, gerekli } \\
\text { kitaplar ve kaynaklar enstitü tarafindan zamanında gönderilmeli }\end{array}$ & 13 & 72 \\
\hline $\begin{array}{l}\text { Ders programları yeniden yapılandırılmalı, kaynaklar bu doğrultuda hazırlanmalı } \\
\text { Türkiye'den giden görevliler gerekli liyakate sahip olmalı, Türkçe öğretimi alanında } \\
\text { araştırmalar yapmalı ve birikimlerini literatüre aktarmalı, Türkçe öğretme aşkıyla görev } \\
\text { yapmalı, öğretici görevlendirmeleri zamanında ve sistemli yapılmalı }\end{array}$ & 9 & 50 \\
\hline $\begin{array}{l}\text { Farklı ülke ve bölgelere özgü Türkçe öğretim yöntemi geliştirilmeli, Arap dilliler, Fars } \\
\text { dilliler, Türk dilliler ve Slav dilliler vb. hedef kitleye yönelik Türkçe öğretim setleri } \\
\text { hazırlanmalı }\end{array}$ & 4 & 22 \\
\hline Türkoloji bölümlerinde eğitim görecek öğrencilerin seçiminde belirli kıstaslar bulunmalı & 4 & 22 \\
\hline TİKA’nın Türkoloji bölümlerine desteği artırılmalı & 3 & 16 \\
\hline Yerel okutmanlar hizmet içi eğitim almalı & 3 & 16 \\
\hline $\begin{array}{l}\text { Yunus Emre Enstitüsü ile yurt dışında Türkçe öğreten kurumlar arasındaki iletişim sağlıklı } \\
\text { olarak yeniden yapılandırılmalı }\end{array}$ & 2 & 11 \\
\hline Türkoloji bölümlerinde edebiyat dersleri, seviyeye uygun sunulmalı & 1 & 5 \\
\hline Çocuklara yabancı dil olarak Türkçe öğretimi hususunda çalışmalar artırılmalı & 1 & 5 \\
\hline
\end{tabular}


Türkçenin yabancı dil olarak yurt dişında öğretimini gerçekleştiren öğretim elemanları, üniversitelerin uygulamalarına bağlı sorunlara yönelik çözüm önerilerini 'üniversiteler fiziki ve teknolojik imkâna kavuşturulmalı, teknik destek sağlanmalı, gerekli kitaplar ve kaynaklar enstitü tarafından zamanında gönderilmeli (\%72)', 'ders programları yeniden yapılandırılmalı, kaynaklar bu doğrultuda hazırlanmalı (\%50)', 'Türkiye'den giden görevliler gerekli liyakate sahip olmalı, Türkçe öğretimi alanında araştırmalar yapmalı ve birikimlerini literatüre aktarmalı, Türkçe öğretme aşkıyla görev yapmalı, öğretici görevlendirmeleri zamanında ve sistemli yapılmalı (\%27)', 'farklı ülke ve bölgelere özgü Türkçe öğretim yöntemi geliştirilmeli, Arap dilliler, Fars dilliler, Türk dilliler ve Slav dilliler vb. hedef kitleye yönelik Türkçe öğretim setleri hazırlanmalı (\%22)', 'Türkoloji bölümlerinde eğitim görecek öğrencilerin seçiminde belirli kıstaslar bulunmalı (\%22)', 'TIKKA'nın Türkoloji bölümlerine desteği artırılmalı (\%16)', 'yerel okutmanlar hizmet içi eğitim almalı (\%16)', 'Yunus Emre Enstitüsü ile yurt dışında Türkçe öğreten kurumlar arasındaki iletişim sağlıklı olarak yeniden yapılandırılmalı (\%11)', 'Türkoloji bölümlerinde edebiyat dersleri, seviyeye uygun sunulmalı (\%5)' ve 'çocuklara yabancı dil olarak Türkçe öğretimi hususunda çalışmalar artırılmalı (\%5)' şeklinde ifade etmişlerdir.

Ö. 11 "Bence mevcut sistemi silkeleyip şimdiye kadar edindiğimiz tecrübelerle yeniden düzenlemelere gitmemiz gerekiyor. Okutmandan ders kaynaklarına kadar her şeyi yeniden kurgulamaya ihtiyaç olduğunu düşünüyorum." şeklinde düşüncelerini ifade etmiştir.

Ö. 12 eğitimde öğretmen yeterliliği üzerinde durmuş ve düşüncelerini "En önemli çözüm, yurt dlşında ögretici görevlendirirken liyakatin esas alınması olacaktır. Mesela, İslami hassasiyetlerin yüksek olduğu bir coğrafyada ben ateistim diyen birini görevlendirmemek gerekir." diyerek öğretmen atamalarında izlenecek gerekliliklerin önemine işaret etmiştir.

Ö. 9 yurt dışında Türkçe öğretimi sürecinde yaşanan sorunlara yönelik çözüm önerilerini "İlgili bölümler (Türkoloji Bölümleri) cazip hâle getirilerek daha başarll öğrencilerin gelmesi sağlanmall, çok öğrenci hedefinden kaliteli ögrrenci hedefine geçilmeli ve doktora mezunu olmayan ögreticiler Türkçe ögretmek üzere gönderilmemeli. ” şeklinde çözüm önerilerine yönelik düşüncelerini dile getirmiştir.

Ö. 5 "Imkanlar, sınıf koşulları, ders materyalleri iyileştirilmelidir. Tüm bölgelerdeki okutmanlar ve ögrenciler ayn imkânlardan faydalanabilmeli. Farklı yerlerdeki tüm okutmanlar dinlenmeli ve ortak problemlere ortak çözümler aranmalıdır. Ögretmenlerin tecrübelerinden ve saha deneyimlerinden faydalanarak tüm becerilere yönelik kaynak kitap çalışmaları ve aktivite çalışmaları yapılmalıdır. Öğretmenlerin dönemleri boyunca buldukları etkinlikler, çalışmalar bir araya getirilip etkileri ve faydaları konuşularak ögrenci için etkili olan, ögrencilerden olumlu dönüt alınan faaliyetler ve çalışmalar bir kaynakta toplanabilir." diyerek sorunların çözümü noktasında bu çalışmanın da konusunu oluşturan hususlara dikkat çekmiştir. Alanda görev yapanların yaşadığı sorunların tespiti, bunlara yönelik çözüm önerileri geliştirilmesi, Türkçenin etkili ve başarılı bir şekilde öğretilmesine katk1 sunacaktır.

\section{Sonuç ve Tartışma}


$\mathrm{Bu}$ araştırmada, yurt dişında yabancı dil olarak Türkçe öğreten öğretim elemanlarının görüşleri doğrultusunda dört temel dil becerisi, dil bilgisi ve görev yapılan üniversitelerin uygulamalarına bağlı sorunlar tespit edilmiş ve yine öğretim elemanlarının görüşlerine göre bu sorunlara çözüm önerileri belirlenmiştir. Araştırmada dinleme, konuşma, okuma, yazma ve dil bilgisi öğretimi ile üniversitelerin uygulamalarına bağlı öne çıkan sorunların sırası ile 'tek tip ses kaydının bulunması, ses kaydı, dinleme cihazı yokluğu ya da yetersizliği', 'öğrencilerin kendi dillerinde olmayan sesleri seslendirmede yaşadıkları zorluğa bağlı sorunlar (özellikle g, ̆g, 1, i, u, ü, o, ö, p sesleri)', 'sesli okuma sürecinde telaffuz, vurgu, tonlama hataları, ders kitabı haricinde okuma metni bulunmaması', 'yazma özyeterliliği düşüklügü, yazma kaygısı, ilgisizlik, yazmaya karşı olumsuz tutum, dil bilgisi hatalarının sık sık tekrar edilmesi', 'önceden öğrenilen yabancı dil konularının ya da ana dilin ileriye ket vurması, öğrencilerin olumsuz tutumu, motivasyon eksikliği, kaygı düzeyi yüksekliği', 'teknik destek, teknoloji yetersizliği, ders programlarına bağlı sorunlar bulunduğu tespit edilmiştir. Bu sorunlara yönelik öne çıkan çözüm önerileri yine aynı dil becerileri sırası ile 'dinleme eğitimi için gerekli teknik cihazlar ve ses kayıtları sağlanmalı', 'konuşma konuları öğrenci ilgisine göre belirlenmeli, konu çeşitliliği sağlanmalı', 'öğrenci düzeyine uygun okuma kitapları yazılmalı, program, müfredat, kitaplar gözden geçirilmeli, seviyeye uygun hâle getirilmeli, kitaplar yaşama uygun işlevsel olmalı', 'süreç temelli yazma eğitimi ile öğrencilere ilgi duydukları konuda daha fazla yazı yazdırılmalı, uygun geribildirim verilmeli', 'dil bilgisi eğitimi dört temel dil becerisinin içerisinde sezdirilerek öğretilmeli', 'Üniversiteler fiziki ve teknolojik imkâna kavuşturulmalı, teknik destek sağlanmalı, gerekli kitaplar ve kaynaklar enstitü tarafindan zamanında gönderilmeli, ders programları yeniden yapılandırılmalı, kaynaklar bu doğrultuda hazırlanmalı' şeklinde belirlenmiştir. Alyılmaz (2010) da Türkçenin ana dili ve yabancı dil olarak öğretimine ciddi sorunlarla karşılaşıldığını, bu sorunların temelde programlardan (ilköğretim Türkçe dersi programlarından, Türkçe öğretmenliği lisans programlarından), takip edilen kitaplardan, öğretim metotlarından, alanla ilgili kurumlardan, öğretim elemanlarından, öğrencilerden...vd. kaynaklandığını ifade etmektedir. Araştırma sonuçları ile Alyılmaz (2010) tarafindan ifade edilen ders programları, öğretim metotları, alanla ilgili kurumlar sorunlarının benzer olduğu görülmektedir. Zenci (2013) de benzer şekilde yabancı dil olarak Türkçe öğretenlerin ders programları ve kitapları hususunda sorunlar yaşadıklarını tespit ederek uygun ders programları ve malzemelerinin hazırlanması gerektiğini belirtmiştir. Filistin'de Türkçe öğretimindeki sorunları tespit eden Tuzlukaya (2019) öğrencilerin alfabe, temel dilbilgisi konuları, kelime bilgisi alanlarında birtakım güçlüklerle karşı karşıya kaldıklarını; eğitim-öğretimle ilgili güçlüklerin; ders işleme süreci, öğretim görevlilerinin yeterlikleri, kaynaklar ve materyal kullanımı alanlarında olduğunu ifade etmiştir. Bu sonuçların araştırma sonuçları ile benzer olduğu görülmektedir.

Tespit edilen sorunlar ve çözüm önerileri, araştırmanın alt problemlerinde belirtilen sıra ile aşağıda sunulmuştur.

Dinleme eğitimi sürecinde öğretim elemanları, 'Tek tip ses kaydı bulunması, ses kaydı yetersizliği', 'dinleme cihazı yokluğu ya da yetersizliği', 'dinleme kaygısı, özyeterlik algısı vb. duyuşsal durumlar', 'dinleme metinlerinin öğrenci seviyesine uygun olmayışı', 'dinleme metinlerindeki konuların ilgi çekici olmayışı', dinleme metinlerinin ilgili kurdaki dil bilgisi yapılarına uygun olmaması', 'dinleme 
kayıtlarının CD şeklinde olması, son dönem bilgisayarlarda CD okuyucu bulunmaması, kayıttan dinleme güçlüğü, internet bağlantısı sıkıntısı', 'eğitim ortamının gürültülü olması nedeni ile dinlemenin sekteye uğraması', 'öğrencilerin ana dillerinde olmayan sesleri dinlemede zorluk yaşaması', 'dinlemeye ayrılan ders saati süresinin yetersizliği' ve 'öğretim görevlisinin Türkçeyi yöresel ağız özellikleri ile kullanması' konularında sorunlar yaşamaktadırlar. Dinleme eğitimi sorunlarında özellikle dinleme yaptırılabilecek teknolojik araç-gereç ve materyal eksikliği dikkati çekmektedir. Arslan ve Adem (2010) de bu konuya dikkat çekmişler ve yabancı dil olarak Türkçenin öğretiminde materyal eksikliği bulunduğunu ve bu eksikliğin öğrenmeyi olumsuz yönde etkilediğini ifade etmişlerdir. Karazeybek (2016) de Arnavutluk'ta Türkçe öğretimi sürecinde materyal eksikliğine bağlı sorunlar bulunduğunu dile getirmiştir. Özdemir, Ruşid, Çevik, Yerlikaya ve Ali (2016) Makedonya' da dinleme becerisinde öğrencilerin söz varlıklarının özellikle A1 ve A2 seviyesinde yeni oluşmasına bağlı sorunları olduğunu, orta seviyedeki sorunları ise mizah, deyim ve atasözlerini anlamada zorluk yaşamaları şeklinde belirtmişlerdir.

Dinleme eğitimi sürecinde yaşanan sorunlara yönelik öğretim elemanları tarafından 'dinleme eğitimi için gerekli teknik cihazlar sağlanmalı', 'dinleme metinleri kur düzeyinde ayarlanmalı, daha yavaş seslendirilmesi ve dinleme ders saati artırılmalı', 'dinleme metinleri görsel destekli videolar şeklinde olmalı', 'Türk edebiyatı metinleri, güncel ilgi çekici, günlük yaşama uygun metinler seviyeye uygun olarak seslendirilmeli', 'Türk kültürünü, yaşayışını, şehirlerini anlatan, tanıtan düzeye uygun görsel ve işitsel videolar hazırlanmalı', 'dinleme metinleri ilgili kurdaki dil bilgisi yapılarını içerir şekilde seviyeye göre hazırlanmalı' ve 'Türkçe alt yazılı filmlerden kesitler ya da çizgi filmler seviyeye göre hazırlanmalı' önerileri sunulmuştur.

Türkçenin yabancı dil olarak yurt dışında öğretiminde konuşma eğitimi sürecinde 'öğrencilerin kendi dillerinde olmayan sesleri telaffuz ederken zorlanması', 'akıcı konuşma yetersizliği', 'özyeterlik algısı eksikliğine bağlı çekinme, komik duruma düşme, yanlış yapma korkusu, konuşma kaygısı', 'söz varlığının sınırlı olması, çeşitlilik/alan yoksunluğu', 'kitaplarda konuşma metinlerinin azlığı, güncel olmaması, doğrudan konuşmaya yönelik kaynak bulunmaması, öğretilen dil bilgisi konusu ile metnin ilişkisinin olmaması', 'konuşmaya karşı ilgisizlik', 'gramer kurallarını konuşma sürecine yansıtamama', 'vurgu ve tonlamada yaşanan zorluklar', 'sınıflarda öğrenci sayısının fazlalı̆̆ı' ve 'derse devam sorunu' başlıklarında sorunların toplandığı görülmektedir. Karazeybek (2016) de benzer bulgulara ulaşmış, Arnavutluk’ta yabancı dil olarak Türkçe öğrenen öğrencilerin vurgu ve ritim, telaffuz ve ahenk, söz dizimi, kelime zenginliği ve cümle kurgusu yönünden konuşma sürecinde zorluk yaşadıklarını belirtmiştir.

Konuşma eğitimi sürecinde başarılı bir öğretimin yapılabilmesi için 'konuşma konuları öğrenci ilgisine göre belirlenmeli, konu çeşitliliği sağlanmalı', 'ders kitaplarında konuşma metinleri artırılmalı, kitaplardaki konular ve etkinlikler gözden geçirilmeli, konuşma eğitimine yönelik kaynak kitaplar, örnek konuşma videoları olmalı', 'Türkçe öğretecek öğretmenlerin seçimi dikkatle gerçekleştirilmeli, öğretim elemanlarının ana dili Türkçe olmalı', 'öğrenci-öğretmen iletişimi yakınlık içermeli, uygun geribildirim verilmeli', 'konuşma ders saatleri artırılmalı', 'sınıftaki öğrenci sayıları uygun şekilde olmalı', 'kelime öğretimine önem verilmeli', 'drama, tiyatro, şiir etkinliklerine yer verilmeli', 'öğrencilerin derse devamı sağlanmalı', 'eğiticiler 
için yönlendirici kaynak kitaplar hazırlanmalı' ve 'dinleme becerisi ve konuşma becerisi birbirini desteklemeli' önerileri getirilmiştir.

Türkçenin yabancı dil olarak yurt dışında öğretimi sürecinde okuma eğitiminde; 'sesli okuma sürecinde telaffuz, vurgu, tonlama hataları', 'ders kitabı haricinde okuma metni bulunmaması', 'okuma kaygısı, motivasyon eksikliği', 'seviyeye uygun okuma metni bulma sıkıntıs1, mevcut kitaplarda yer alan metinlerin uzun olması, metinlerin dil bilgisi konularıyla bağdaşmaması, etkinliklerin seviye üzerinde olması', 'söz varlığı yetersizliği', 'okuduğunu anlama güçlüğü, deyimler ve atasözlerinin bulunduğu metinlerin güç anlaşılması', 'öğrenci sayısının sınıflarda fazla olması' ve 'sözlük kullanma alışkanlığının olmaması' başlıklarında sorunlarla karşılaşıldığı görülmektedir. Karazeybek (2016) Arnavutluk’ta Türkçe öğretirken okuma becerisine yönelik sorunların öğrencilerin ana dilleri ile hedef dil arasındaki yapı farklılığı, ana dillerindeki sesletim ve vurguları koruma eğilimleri ve Türkçedeki yabancı kökenli sözcükler olduğunu belirtmiştir. Bu sorunlar arasında bulunan sesletim sorunlarının araştırma sonuçları ile benzer olduğu görülmektedir. Özdemir, Ruşid, Çevik, Yerlikaya ve Ali (2016) Makedonya'da okuma eğitimi sürecinde öğrencilerin yazı dilinin Kiril alfabesi olması nedeni ile sorunlar yaşandığını belirtmişılerdir. Araştırma bulguları ile diğer araştırma bulguları arasında en dikkat çeken sorunun alfabe, ses farklılıklarına bağlı telaffuz, vurgu, tonlama hatalar1 olduğu görülmektedir. Yörüsün, Kardaş ve Erdoğan (2016) da Kosova'da okuma eğitimi sürecinde öğrencilerin Türkçedeki uzun hecelerden ve ana dillerinde bulunmayan harflerin ( $\breve{g}$ ve ö gibi) sesletimlerinden kaynaklı sorunlar yaşadıklarını belirtmişlerdir.

Öğretim elemanları; 'öğrenci düzeyine uygun okuma kitapları yazılmalı', 'program, müfredat, kitaplar gözden geçirilmeli, seviyeye uygun hâle getirilmeli', 'kitaplar yaşama uygun ve işlevsel olmalı', 'sesli okumada vurgu, tonlama ve telaffuza dikkat edilmeli', 'sınıflardaki öğrenci sayıları az olmalı, ders saati artırılmalı', ‘öğretmenler öğrencilerini teşvik edecek şekilde davranmalı', 'öğrenciler sözlük kullanma alışkanlığı edinmeli, söz varlıkları artırılmalı', 'metinler öğretim elemanları tarafından temin edilmeli', 'dünya masalları yabancı öğrencilere göre hazırlanmalı', 'tüm dinlerde ortak olan kıssalar yabancı öğrenciler için kitaplaştırılmalı' ve 'başka ülkelerin kültür ve tarih ögelerine yer veren metinler hazırlanmalı’ önerilerini okuma eğitimindeki sorunların çözümü için sunmuşlardır.

Türkçenin yabancı dil olarak yurt dışında öğretiminde yazma eğitimine yönelik 'yazma özyeterliği düşüklüğü, yazma kaygısı, ilgisizlik, olumsuz tutum' gibi duyuşsal duruma bağlı sorunların sıklıkla yaşandığı görülmektedir. Maden, Dincel ve Maden (2015) yabancı uyruklu öğrencilerin Türkçe yazarken çoğunlukla kaygılandıklarını ortaya koymuşlardır. Çalışmada ayrıca 'dil bilgisi hatalarının sık sık tekrar edilmesi', 'alfabe farklılığı, seslere hâkim olamama', 'çok heceli sözcüklerde sesleri karıştırma, (b, d/ c, ç/ i, 1/ o, ö/ u, ü)', 'söz varlığı sınırlılığı', 'ders kitaplarında yazma etkinliklerinin hayatın içinden olmayışı, aynı konuların tekrar etmesi, yönergelerin açık olmaması', 'cümle diziminde yapılan yanlışlıklar', 'büyük-küçük harf kuralına uymama' ve 'noktalama işareti yanlışlıkları' sorunlarının bulunduğu ifade edilmiştir. Genç (2017) araştırma bulguları ile benzer şekilde Türk Dili’nin ünlü-ünsüz uyumu, ünsüz yumuşaması gibi kimi yapısal özellikleri, Batı dillerinde olmayan /ö/, / /u/, / /g/, /ç/, /ş/ seslerinin Türkçe öğrenen yabancılar için zor olduğunu, Alfabe öğretimini sözcük öğretiminin izlediğini ifade 
etmiştir. İbragiç (2017) yapmış olduğu çalışmasında Bosna Hersek’te yabancı dil olarak Türkçe öğrenen A düzeyindeki ilköğretim öğrencilerinin yazma sorunlarını tespit etmiş, neticesinde öğrencilerin kompozisyon yazarken çoğu zaman kendi ana diline uyarlamalar yaptıklarını, ses/harf açısından birtakım sorunlar ortaya çıktığını, Boşnak alfabesinde ' 1 , ö, ü, 乌̆' harfleri olmadı̆̆ için kelimelerde bu harfleri yazamadıklarını, kelimeleri yanlış yerde kullandıklarını, öğrencilerin cümle dizilişini kavrayamadıklarını ifade etmiştir. Bu çalışmadaki cümle dizimi, sesleri karıştırma sonuçlarının araştırma sonuçları ile benzer olduğu görülmektedir. Karazeybek (2016) Arnavutluk’ta Türkçe yazma becerisi eğitiminde araştırma bulguları ile benzer şekilde yazım hataları, yanlış veya gereksiz ek kullanımı, ek sıralama hataları, fiil eksikliği, özne-yüklem uyumsuzluğu, yanlış sözcük seçimi, söz dizimi sorunlarının bulunduğunu tespit etmiştir. Yörüsün, Kardaş ve Erdoğan (2016) Kosova'da Türkçe yazma becerisi eğitiminde harf, ek, sözcük düzeyinde yapılan hatalar, ses olayları ve uyumu ile ilgili hatalar bulunduğunu ortaya koymuşlardır. Özdemir, Ruşid, Çevik, Yerlikaya ve Ali (2016) Makedonya'da yazma becerisinde yaşanan sorunların kaynağının alfabe farklılığı olduğunu belirtmişlerdir. İpek (2016) Polonya'da Türkçe dil bilgisi öğretiminde telaffuz, söz dizimi, isim tamlamaları, hâl ekleri, zamir n'si, A1 kurunda çokluk eki, belirsiz geçmiş zaman, B1 ve B2 kurunda ettirgen yapı, isim-fiiller ve yazma yanlışları sorunları bulunduğunu tespit etmiştir.

Yazma eğitimi sürecinde yaşanan sorunlara yönelik öğretim elemanları tarafindan 'öğrencilerin ilgi duydukları konuda daha fazla yazı yazdırılmalı', 'uygun geribildirim verme, öğrencilerin yazdıklarını sürekli kontrol etme', 'yazma eğitimine yönelik kaynak kitap oluşturulmalı', 'süreç temelli yazma eğitimi verilmeli', 'ders kitaplarındaki yazma konuları hayatın içinden olmalı', 'yazma eğitimini desteklemek için öğrencilerin kitap okuma oranı artırılmalı', 'dikte çalışmalarına fazla yer verilmeli' ve 'yazma etkinlikleri sanal ortama da taşınmalı, portfolyo uygulaması yapılmalı’ önerileri getirilmiştir. Genç (2017) yabancı dil olarak Türkçe öğrenenler için yazma becerisinin diğer dilsel becerilere göre en fazla göz ardı edilen ancak en zor geliştirilen beceri olduğunu ifade etmiş ve yabancılara Türkçe öğretiminde yazma becerilerini geliştirme çalışmalarında öncelikle öğrencilerin dil düzeyine uygun olan çalışma ve etkinliklerin belirlenmesinin oldukça önemli olduğunu belirtmiştir.

Dil bilgisi öğretimi sürecinde 'önceden öğrenilen yabancı dil konularının ya da ana dilin ileriye ket vurması', 'öğrencilerin olumsuz tutumu, motivasyon eksikliği, kayg1 düzeyi yüksekliği', 'dil bilgisi öğretimine yönelik kaynak eksikliği', 'teknolojik araç-gereçlerden eğitim sürecinde yararlanamama', 'ders kitaplarında yer alan gramer konularının sıralaması, dil bilgisi kurallarının etkinliklere yeteri kadar yerleştirilememesi', 'ses olayları, fiilimsiler' ve 'Türkçeye maruz kalamama' sorunlarının bulunduğu tespit edilmiştir. Çangal ve Hattatioğlu (2016) BosnaHersek’te yabancı dil olarak Türkçe öğretirken alfabe, söz dizimi, var-yok yapısı, isim-fiil ekleri, isim tamlamaları, zamanlar, durum ekleri, ettirgen-oldurgan fiiller, zamir n'si, yardımc fiil “-DIr”, “-II” ve "-sIz” ekleri ve tarihlerin öğretimi gibi dil bilgisi sorunlarının yaşandığını belirtmişlerdir. Başutku, Kaya ve Tomak (2016) Macaristan'da yabancı dil olarak Türkçe öğrenenlerin alfabe farkı, hâl ekleri, zamanlar, edilgen-dönüşlü-ettirgen-oldurgan çatılar, şahıs ve iyelik ekleri, edatlar ve çokluk eki konularında dil bilgisi sorunları yaşadıklarını belirtmişlerdir. Özdemir, Ruşid, Çevik, Yerlikaya ve Ali (2016) Makedonya'da Türkçe öğretiminde alfabe, 
söz dizimi, var-yok ve yok değil yapıları, işaret zamirleri, hâl ekleri, isim-fiiller, edilgen-dönüşlü-ettirgen-oldurgan çatılar, şahıs ve iyelik ekleri, edatlar ve çokluk ekinde yaşanan sorunlar bulunduğunu dile getirmişlerdir. Mısır'da da benzer sorunlar yaşanmakta, bunlar dil bilgisi öğretimi sürecinde hâl ekleri, Türkçede erillik, dişilik kavramının olmaması, şahıs ekleri (Özdemir, Yazıcı \& Shiha, 2016), alfabe, söz dizimi, işaret zamirleri, var-yok ve yok-değil yapısı, hâl ekleri, isimfiiller, çatı ekleri, bağlaç ve edatlar, tamlamalar ve zamanlar (Hamaratlı, Aydoğdu, İltar, Mantı, Samuel, Zakaria \& Akto, 2016) başlıklarında toplanmaktadır. Salduz ve Akbulut (2016) Gürcistan'da yabancı dil olarak Türkçe öğrenenlerin yaşadıkları dil bilgisi sorunlarını büyük harflerin yazımında yaşanan sorunlar, var-yok yapısında yaşanan sorun, işaret zamirlerinin kullanımı sorunu, değil ve yok yapılarında karşılaşılan sorun, geniş zamanın kullanımındaki sorun, isim-fiil eklerinde görülen sorun, "DIr"'ın kullanımındaki sorun, yüzdelik ifadelerin yazımı sorunu ve saatlerin söylenişinde yaşanan sorunlar şeklinde ifade etmişlerdir. Araştırmada zikredilen büyük-küçük harf, alfabe, söz dizimi gibi sorunların bu sorunlarla benzer olduğu görülmektedir.

Türkçenin yabancı dil olarak öğretilmesi sürecinde dil bilgisi eğitiminde karşılaşılan sorunlara yönelik olarak getirilen çözüm önerileri 'dil bilgisi eğitimi dört temel dil becerisinin içerisinde sezdirilerek öğretilmeli’, 'öğretim elemanları kitaba bağlı kalmaksızın güncel hayatı içeren dil bilgisi etkinlikleri tasarlamalı, bulunduğu yörenin yerel, kültürel özellikleri işe koşulmalı, farklı yöntem ve teknikler kullanılmalı', 'eğitim teknolojilerinden yararlanma imkânı sağlanmalı' ve 'öğretime yönelik materyal temini, kaynakların Türkçenin dil yapısına uygun hazırlanması' şeklinde sıralanmaktadır.

Türkçenin yurt dışında öğretiminde çalışılan üniversitelerin uygulamalarına bağlı sorunlar şu şekilde tespit edilmiştir: 'Teknik destek, teknoloji yetersizliği', 'ders programları', 'ders saati yetersizliği', 'dersliklerin fiziki yetersizliği', 'ülkelerde yaşanan siyasî sorunlar nedeniyle eğitimin kesintiye uğraması, tatillerin fazlalığı, bürokratik işlemlerin uzun sürmesi', 'öğrenci ilgisizliği, motivasyon düşüklüğü, özgüven eksikliği, ders devamsızlı̆̆ı', 'kitap kullanımını kısıtlama, engelleme, defter, kalem yokluğu, eğitim materyali eksikliği', 'ders kitabı dışında yeterli akademik ve yazınsal kaynağın çoğu bölümde olmaması', 'öğrencilerin Türkiye'de yaşamadıkları için dile maruz kalamayışları', 'öğretim elemanı yetersizliği', 'öğretmenlerin mesleki yetersizliği', ‘öğretim tekniği yanlışlığı', ‘öğrenci seviyelerinin ilk girişten itibaren düşük olması', 'yerel öğreticilerin Türkoloji’ye ve alana ilişkin formasyonunun zayıf olması' ve 'Türkiye'den gönderilen akademisyenlerin alana uzak olması'. Barın (2004) yabancı dil olarak Türkçenin öğretimi alanının ayrı bir disiplin olduğunu ve bu alana uygun uzman öğretim elemanlarının yetiştirilmesi konusuna daha çok önem verilmesi gerektiğini ifade etmiştir. Göçer (2009) de benzer şekilde yabancı dil olarak Türkçeyi öğretecek nitelikli öğretmenlerin eksik olduğunu ve altyapısı uygun üniversitelerde yabancı dil olarak Türkçe öğretmenliği bölümlerinin açılması gerektiğini belirtmiştir. Araştırmacılar tarafindan dile getirilen sorunların aradan uzun bir zaman geçmiş olmasına rağmen araştırma bulguları paralelinde düşünüldüğünde devam ettiği görülmektedir.

Türkçenin yabancı dil olarak yurt dışında öğretimini gerçekleştiren öğretim elemanları, üniversitelerin uygulamalarına bağlı sorunlara yönelik çözüm önerilerini 
'üniversiteler fiziki ve teknolojik imkâna kavuşturulmalı, teknik destek sağlanmalı, gerekli kitaplar ve kaynaklar enstitü tarafından zamanında gönderilmeli', 'ders programları yeniden yapılandırılmalı, kaynaklar bu doğrultuda hazırlanmalı', 'Türkiye'den giden görevliler gerekli liyakate sahip olmalı, Türkçe öğretimi alanında araştırmalar yapmalı ve birikimlerini literatüre aktarmalı, Türkçe öğretme aşkıyla görev yapmalı, öğretici görevlendirmeleri zamanında ve sistemli yapılmalı', 'farklı ülke ve bölgelere özgü Türkçe öğretim yöntemi geliştirilmeli, Arap dilliler, Fars dilliler, Türk dilliler ve Slav dilliler vb. hedef kitleye yönelik Türkçe öğretim setleri hazırlanmalı', 'Türkoloji bölümlerinde eğitim görecek öğrencilerin seçiminde belirli kıstaslar bulunmalı', 'TİKA'nın Türkoloji bölümlerine desteği artırılmalı', 'yerel okutmanlar hizmet içi eğitim almalı', 'Yunus Emre Enstitüsü ile yurt dışında Türkçe öğreten kurumlar arasındaki iletişim sağlıklı olarak yeniden yapılandırılmalı', 'Türkoloji bölümlerinde edebiyat dersleri, seviyeye uygun sunulmalı' ve 'çocuklara yabancı dil olarak Türkçe öğretimi hususunda çalışmalar artırılmalı' şeklinde ifade etmişlerdir.

Candaş Karababa (2009) ülkemizde yaşanan sorunları, Türkçenin dilbilgisini işlevsel açıdan ve her yönüyle betimleyen çalışmaların yeterli olmaması, öğretim programı eksikliği, ders öğretim araç gereçleri ve ders kitabı yetersizliği, Türkçeyi öğrenenlerin çeşitliliğine uygun olarak hazırlanmamış, ‘tek tip öğretim programı' ve buna koşut oluşturulan ders araç-gereçleri ve ders kitaplarının öğretim ortamlarını olumsuz yönde etkilemesi, karma sınıflarda farklı kültürlere duyarlı öğretim elemanı gerekliliği, öğrenci açısından Türkçe öğrenimi sürecinde Türkçenin sesletimi, biçim bilgisi ve tümce yapısından kaynaklanan çeşitli sorunlar ile öğrencilerin anlamaya ve anlatmaya bağlı sorunlar olarak sıralamıştır. Program sorunu, ders araç-gereçleri ve kitaplarına yönelik eksiklikler, Türkçe seslere ilişkin telaffuz sorunları, her iki araştırmanın benzer sonuçları olarak değerlendirilebilir.

Maden ve İşcan (2011) Hindistanlı öğrencilerin Türkçe öğrenirken daha çok gramer alanında, konuşma ve kelime hazinesi eksikliği alanlarında sorun yaşadıkları sonucuna ulaşmışlardır. Söz konusu sonuçlar, araştırma bulguları ile benzerlik göstermektedir.

Okur ve Onuk (2013) çalışmalarında ülkemizde yabancılara Türkçe öğretiminde yaşanan sorunları 13 ayrı başlıkta değerlendirmişlerdir. $\mathrm{Bu}$ başlıklar; kültür farklılığı, ders araç gereçlerinin niteliği, eğitimcilerin yetersizliği, Türkçe öğretimi için hazırlanan eserlerden, yöntem ve tekniklerden, sahne oyunlarından ve oyunlardan yeterince yararlanılmamasından, atasözü ve deyimlerin doğru öğretilmemesinden, bazı eş görevli yapı ve sözcüklerin anlam farklılığından, yardımcı fiillerin yanlış öğretilmesinden, zaman kaymalarından ve yabancı sözcük kullanma merakından kaynaklanan sorunlar başlıklarıdır. Okur ve Onuk (2013) tarafindan belirlenen Türkiye'de yabancı dil olarak Türkçe öğretiminde yaşanan sorunların yurt dışında da benzer şekilde yaşandığı araştırma sonuçlarında görülmektedir.

Sevindik, Okur ve Curtomer (2016) Romanya'da Türkçe öğretiminde karşılaşılan sorunları araştırmışlar ve alfabede, söz diziminde, var-yok yapısında, yönelme ve bulunma hâlinde, edatlar ve "en" zarfinda, görülen geçmiş ve gelecek zamanda, çokluk ekinde, temel soru kalıplarında, tamlamalara getirilen eklerde, vurgu ve tonlamada, ortak söz varlığında ve işaret zamirlerinde sorunlar bulunduğunu 
belirtmişlerdir. Pek çok araştırma sonucunda da olan bu bulguların, araştırma sonuçları ile alfabe, söz dizimi, vurgu ve tonlama gibi ortak sorunları olduğu görülmektedir.

Gürler, Türkyılmaz, Türkyılmaz ve Tamkoç (2016) da Ürdün'de Türkçe öğretiminde alfabe, çokluk eki, hâl ekleri, şahıs ve iyelik ekleri, zamanlar, işaret zamirleri, isim-fiil ekleri, isim ve sıfat tamlamaları, kalıp sözler, yok-değil yapısı, var-yok yapısı saatlerin öğretimi, mahalli idareler ve yerel yönetimlerin öğretimi, bağlaç ve edatlar, çok anlamlı sözcükler, kültür farklılığı sorunlarına değinmişlerdir. Araştırma sonuçları ile ortak bulguların alfabe, sözcük öğretimi, kültür farklılığ sorunları olduğu görülmektedir.

Yağc1 (2017) Belarus’ta Türkçenin öğretiminde karşılaşılan sorunları tespit etmiştir. Bunlar; cümle yapılarındaki benzerlik ya da farklılıkların etkisi, Rusçada soru ekinin bulunmayışı, hâl eklerinin öğretiminde yaşanan sorunlar ayrıntılı olarak açıklanmıştır. Yazma becerisinde karşılaşılan sorunlar başlığında c, ç, ğ, i, ö, ş ve ü harflerinin yanlış yazılışı, yazım ve noktalama ile ilgili yanlışlar ve öğrenme sürecini etkileyen psikolojik faktörler ele alınmıştır. $\mathrm{Bu}$ sonuçlar araştırma ile benzerlik gösteren sonuçlar olarak görülmektedir. Çalışmada ayrıca ülkeler arası uzaklık, yabancı kültüre karşı korunma, dinsel inanç farklılıkları, ülkeler arasında kültürel faaliyetlerin azlığı, Türkçenin zor bir dil olduğu düşüncesi, Türkçenin iş sahasındaki karşılığı, bireysel ve çevresel faktörler, derse ayrılan zaman ve öğretim materyallerinin eksikliği başlıklarında sorunlar tespit edilmiş ve çeşitli öneriler getirilmiştir. Yağcı (2017) tarafindan Belarus’ta Türkçenin öğretiminde karşılaşılan duyuşsal sorunlar, öğretim materyali eksikliği, derse ayrılan zaman süresi yetersizliği, belirli harflerin yazımında zorluk gibi bulguların da araştırma sonuçlarıyla benzer olduğu görülmektedir.

Er, Biçer ve Bozkırlı (2012) da Türkçenin yurt dışında öğretimi sürecinde tespit edilen sorunlara benzer şekilde sorunlar bulunduğunu, ilgili literatürde yer alan 34 makaleyi incelemek yoluyla ortaya koymuşlardır. İncelenen makalelerde yabancılara Türkçe öğretimiyle ilgili ders öğretim araç gereçleri bakımından yaşanan yetersizlikler, öğretim programı yetersizliği, Türkçe öğretimi alanının farklı ana bilim dallarına ayrılmamış olması, öğrencilerle ilgili sorunlar, lisans ve lisansüstü düzeyde görevli öğretim elemanlarıyla ile ilgili sorunlar, teknolojik bakımdan yaşanan yetersizlikler, Türkçenin yabancı dil olarak öğretiminde yararlanılabilecek kaynakların yetersizliği, Türkçe öğretimi ile ilgilenen kurumlarla ilgili sorunlar, eğitim öğretim ortamı bağlamındaki yetersizlikler, kullanılan yöntem ve teknikler bakımından yaşanan sıkıntılar olduğu görülmüştür. 2012 yılında tespit edilen bu sorunların yurt dışında Türkçe öğretiminde bu araştırmanın yapılmış olduğu 2020 yılında da devam ediyor olması, araştırma sonuçlarının bir an önce dikkate alınarak ilgililerce gerekli adımların atılması gerektiğini göstermektedir.

\section{Öneriler}

$\mathrm{Bu}$ çalışma ile Türkçenin yabancı dil olarak yurt dışında öğretilmesi sürecinde yaşanan sorunlar tespit edilmiş, çözüm önerileri belirlenmiştir. Tüm bunların yabancı dil olarak Türkçe öğreten, program yapan, kitap yazanlar tarafindan dikkate alınması, araştırma verileri ışı̆̆ında bu çalışmaların yeniden yapılandırılması önerilmektedir. 
$\mathrm{Bu}$ çalışmada veriler, 12 farklı ülkeden 18 öğretim görevlisinin görüşleri alınarak elde edilmiştir. Araştırmacılar tarafından çalışma bir ön basamak olarak görülmeli, yurt dışında görev yapan tüm öğretim elemanlarından sorunların neler olduğu öğrenilmeli, çözüm önerileri alınmalı ve bu bağlamda çalıştaylar düzenlenerek Türkçenin çağdaş eğitim ve öğretim yaklaşımları doğrultusunda etkin öğretilmesine yönelik programlar, ders kitapları yeniden gözden geçirilmelidir.

Türkçe öğretiminde özellikle alfabeden yani dile özgü seslerden kaynaklı sorunlar bulunduğu görüldüğünden mevcut öğretim materyallerine ek olarak öğretim yapılan ülkelere özgü materyallerin hazırlanması gerekmektedir.

Türkçenin yabancı dil olarak yurt dışında öğretilmesi sürecinde Türkoloji bölümlerinin ders programları gözden geçirilmeli, ülkelerle kurulacak ikili ilişkilerle bu programlar yeniden düzenlenmelidir.

Araştırmacılara, çalışmada ortaya konulan sorunların giderilmesine yönelik deneysel çalışmalar yapmaları önerilmektedir.

\section{Çıkar Çatışmasıı ve Etik Bildirimi}

Araştırma için gerekli etik kurul onayının Aydın Adnan Menderes Üniversitesi Eğitim Araştırmaları Etik Kurulunun 06.10.2020 tarihli ve 84982664-050.01.04 sayılı yazısı ile 2020/15 numaralı toplantıda alındığını, araştırmanın tüm süreçlerinde etik kurallara uyulduğunu beyan ederim.

\section{Kaynakça}

Açık, F. (2008). Türkiye'de yabancılara Türkçe öğretilirken karşılaşılan sorunlar ve çözüm önerileri. Uluslararası Türkçe Eğitimi ve Öğretimi Sempozyumu, 27-28 Mart, Gazimağusa/ Kuzey Kıbrıs.

Altunışık, R., Coşkun, R., Bayraktaroğlu, S., \& Yıldırım, E. (2005). Sosyal bilimlerde araştırma yöntemleri. Sakarya Kitabevi.

Alyılmaz, C. (2010). Türkçe öğretiminin sorunları. Turkish Studies International Periodical for the Languages, Literature and History of Turkish or Turkic, 5(3), 728-749. http://dx.doi.org/10.7827/TurkishStudies.1629

Arslan, M., \& Adem, E. (2010). Yabancılara Türkçe öğretiminde görsel ve işitsel araçların etkin kullanımı. Dil Dergisi, 147, 63-86.

Barın, E. (2004). Yabancılara Türkçe öğretiminde ilkeler. Hacettepe Üniversitesi Türkiyat Araştırmaları Dergisi, 1(1), 19-30. https://dergipark.org.tr/tr/pub/turkiyat/issue/16660/329608

Başutku, S., Kaya, S., \& Emine, T. (2016). Macaristan'da Türkçe öğretimi, karşılaşılan güçlükler ve çözüm önerileri. H. Develi, Ş. Ateş, Ş. Çobanoğlu, M. Balcı, İ. Gültekin, N. Temur, R. Ademi, M. Kurt, İ. Erdem, H. Karatay, D. Melanlığlu, O. Mert, S. Pilav, \& M. Ülker (Ed.), Türkçenin yabancı dil olarak ögretiminde yöntem ve uygulamalar içinde (ss.169-210). Kültür Sanat Basımevi.

Boylu, E., \& Başar, U. (2015). Televizyondan yabancı dil olarak Türkçe öğrenimine ilişkin bir durum tespiti çalışması: İran örneği. International Journal of Language Academy 3(4), 401-414. http://dx.doi.org/10.18033/ijla.311 
Candaş Karababa, Z. C. (2009) Yabancı dil olarak Türkçenin öğretimi ve karşılaşılan sorunlar. Ankara Üniversitesi Eğitim Bilimleri Fakültesi Dergisi, 42(2), 265-277. https://doi.org/10.1501/Egifak_0000001185

Çangal, Ö., \& Hattatioğlu, A. (2016). Bosna-Hersek’te Türkçe öğretimi, karşılaşılan güçlükler ve çözüm önerileri. H. Develi, Ş. Ateş, Ş. Çobanoğlu, M. Balcı, İ. Gültekin, N. Temur, R. Ademi, M. Kurt, İ. Erdem, H. Karatay, D. Melanlıoğlu, O. Mert, S. Pilav, \& M. Ülker (Ed.), Türkçenin yabancı dil olarak ögrretiminde yöntem ve uygulamalar içinde (ss. 71112). Kültür Sanat Basımevi.

Demirel, Ö. (1993). Yabancı dil ögrretimi ilkeler, yöntemler, teknikler. Usem Yayınları.

Durmuş, M. (2013). Türkçenin yabancılara öğretimi: Sorunlar, çözüm önerileri ve yabancılara Türkçe öğretiminin geleceğiyle ilgili görüşler. Adlyaman Üniversitesi Sosyal Bilimler Enstitüsü Dergisi Türkçenin Ĕgitimi Öğretimi Özel Saylsı, 6(11), 207-228. https://doi.org/10.14520/adyusbd.488

Er, O., Biçer, N., \& Bozkırlı, K. Ç. (2012). Yabancılara Türkçe öğretiminde karşılaşılan sorunların ilgili alan yazını 1şı̆̆ında değerlendirilmesi. Uluslararası Türkçe Edebiyat Kültür Eğitim Dergisi, 1(2), 51-69. http://dx.doi.org/10.7884/teke.51

Erdem, İ. (2009). Yabancilara Türkçe öğretimiyle ilgili bir kaynakça denemesi. Turkish Studies International Periodical For the Languages, Literature and History of Turkish or Turkic. 4(3), 888-937. http://dx.doi.org/10.7827/TurkishStudies.709

Genç, H. N. (2017). Yabancı dil olarak Türkçe öğretiminde yazma eğitimi bağlamında yazım ve noktalama. Ankara Üniversitesi TÖMER Dil Dergisi, 168(2), 31-42. https://doi.org/10.1501/Dilder_0000000242

Göçer, A. (2009). Türkiye'de Türkçeyi yabancı dil olarak öğreten öğretmenlerin uygulamalarına yönelik nitel bir araştırma. Dil Dergisi, 145, 28-47. https://doi.org/10.1501/Dilder_0000000114

Gürler, S., Türkyılmaz, E. Ç., Türkyılmaz, N., \& Tamkoç, F. (2016). Ürdün'de Türkçe öğretimi, karşılaşılan güçlükler ve çözüm önerileri (Bükreş örneği). H. Develi, Ş. Ateş, Ş. Çobanoğlu, M. Balcı, İ. Gültekin, N. Temur, R. Ademi, M. Kurt, İ. Erdem, H. Karatay, D. Melanlığlu, O. Mert, S. Pilav, \& M. Ülker (Ed.), Türkçenin yabancı dil olarak ögretiminde yöntem ve uygulamalar içinde (ss. 481-511). Kültür Sanat Basımevi.

Hamaratl1, E., Aydoğdu, İ., İltar, L., Mantı, M. İ., Samuel, M., Zakaria, S., \& Akto, T. (2016). Mısır'da Türkçe öğretimi, karşılaşılan güçlükler ve çözüm önerileri (Kahire örneği). H. Develi, Ş. Ateş, Ş. Çobanoğlu, M. Balcı, İ. Gültekin, N. Temur, R. Ademi, M. Kurt, İ. Erdem, H. Karatay, D. Melanlığlu, O. Mert, S. Pilav, \& M. Ülker (Ed.), Türkçenin yabancı dil olarak öğretiminde yöntem ve uygulamalar içinde (ss. 297-348). Kültür Sanat Basımevi.

İbragiç, İ. (2017). Bosna Hersek'te ilköğretimde yabancı dil olarak Türkçe A düzeyinde yazma sorunlarl [Yayımlanmamış yüksek lisans tezi]. Hacettepe Üniversitesi.

İpek, S. (2016). Polonya'da Türkçe öğretimi, karşılaşılan güçlükler ve çözüm önerileri. H. Develi, Ş. Ateş, Ş. Çobanoğlu, M. Balcı, İ. Gültekin, N. Temur, R. Ademi, M. Kurt, İ. Erdem, H. Karatay, D. Melanlığlu, O. Mert, S. Pilav, \& M. Ülker (Ed.), Türkçenin yabancı dil olarak ögretiminde yöntem ve uygulamalar içinde (ss.383-424). Kültür Sanat Basımevi.

Karazeybek, A. (2016). Arnavutluk’ta Türkçe öğretimi, karşılaşılan güçlükler ve çözüm önerileri (İşkodra örneği). H. Develi, Ş. Ateş, Ş. Çobanoğlu, M. Balcı, İ. Gültekin, N. 
Temur, R. Ademi, M. Kurt, İ. Erdem, H. Karatay, D. Melanlığlu, O. Mert, S. Pilav, \& M. Ülker (Ed.), Türkçenin yabancı dil olarak ögretiminde yöntem ve uygulamalar içinde (s. 11-42). Kültür Sanat Basımevi.

Maden, S., \& İşcan, A . (2011). Yabancı dil olarak Türkçe öğretimi amaç ve sorunlar (Hindistan örneği). Karadeniz Sosyal Bilimler Dergisi, 3(5), 23-37. https://dergipark.org.tr/tr/pub/ksbd/issue/16226/169931

Maden, S., Dincel, Ö., \& Maden, A. (2015). Türkçeyi yabancı dil olarak öğrenenlerin yazma kaygıları. Uluslararası Türkçe Edebiyat Kültür Eğitim Dergisi, 4(2), 748-769. https://doi.org/10.7884/teke.488

Miles, M. B., \& Huberman, A. M. (1994). Qualitative data analysis: An expanded sourcebook. Thousand Oaks, CA: Sage.

Okur, A., \& Onuk, A. (2013). Yabancılara Türkçe öğretiminde karş1laşılan sorunlara yönelik inceleme. International Journal of Social Science, 6(6), 872-892. http://dx.doi.org/10.9761/JASSS1648

Özdemir, S., Ruşid, F., Çevik, A. İ., Yerlikaya, E., \& Ali, M. (2016). Makedonya'da Türkçe öğretimi, karşılaşılan güçlükler ve çözüm önerileri. H. Develi, Ş. Ateş, Ş. Çobanoğlu, M. Balcı, İ. Gültekin, N. Temur, R. Ademi, M. Kurt, İ. Erdem, H. Karatay, D. Melanlıoğlu, O. Mert, S. Pilav, \& M. Ülker (Ed.), Türkçenin yabancı dil olarak ögretiminde yöntem ve uygulamalar içinde (ss. 211-258). Kültür Sanat Basımevi.

Özdemir, V., Yazıcı, M. H., \& Shiha, M. (2016). Mısır'da Türkçe öğretimi, karşılaşılan güçlükler ve çözüm önerileri (İskenderiye örneği). H. Develi, Ş. Ateş, Ş. Çobanoğlu, M. Balcı, İ. Gültekin, N. Temur, R. Ademi, M. Kurt, İ. Erdem, H. Karatay, D. Melanlığlu, O. Mert, S. Pilav, \& M. Ülker (Ed.), Türkçenin yabancı dil olarak öğretiminde yöntem ve uygulamalar içinde (ss. 259-296). Kültür Sanat Basımevi.

Punch, K. F. (2005). Introduction to social research-quantitative and qualitative approaches. Sage.

Tuzlukaya, S. (2019). Filistinli öğrencilerin Türkçe öğrenirken temel düzeyde (A1-A2) karşılaştıkları ortak güçlükler. Aydın TÖMER Dil Dergisi, 4(1), 3155. https://dergipark.org.tr/tr/pub/aydintdd/issue/44419/512246.

Sevindik, C., Okur, S., \& Curtomer, G. (2016). Romanya'da Türkce öğretimi, karşılaşılan güçlükler ve çözüm önerileri. H. Develi, Ş. Ateş, Ş. Çobanoğlu, M. Balcı, İ. Gültekin, N. Temur, R. Ademi, M. Kurt, İ. Erdem, H. Karatay, D. Melanlığlu, O. Mert, S. Pilav, \& M. Ülker (Ed.), Türkçenin yabancı dil olarak öğretiminde yöntem ve uygulamalar içinde (ss. 425-450). Kültür Sanat Basımevi.

Yağcı, G . (2017). Türkçenin yabancı dil olarak öğretiminde karşılaşılan sorunlar ve çözüm önerileri: Belarus örneği. Türk Dili Araştırmalart Ylllı̆̆l-Belleten, 65(1), 191-199. https://dergipark.org.tr/tr/pub/belleten/issue/33970/375493

Yıldırım, A., \& Şimşek, H. (2005). Sosyal bilimlerde nitel araştırma yöntemleri. (Güncelleştirilmiş ve geliştirilmiş beşinci baskı). Seçkin Yayınları.

Yörüsün, S., Kardaş, M. D., \& Erdoğan, T. (2016). Kosova'da Türkçe öğretimi, karşılaşılan güçlükler ve çözüm önerileri. H. Develi, Ş. Ateş, Ş. Çobanoğlu, M. Balc1, İ. Gültekin, N. Temur, R. Ademi, M. Kurt, İ. Erdem, H. Karatay, D. Melanlığlu, O. Mert, S. Pilav, \& M. Ülker (Ed.), Türkçenin yabancı dil olarak öğretiminde yöntem ve uygulamalar içinde (ss. 143-168). Kültür Sanat Basımevi. 
Zenci, Y. Ç. (2013). Türkçenin yabancı dil olarak öğretiminde karşılaşılan sorunlar. Muhafazakâr Düsünce Dergisi, 10(38), 218. https://dergipark.org.tr/tr/pub/muhafazakar/issue/52848/698560

\section{Extended Abstract}

The need to learn a foreign language due to advances in communication technologies, social media use, bilateral relations and trade is an undeniable reality today. Language instruction does not only include the instruction of the rules and words in a language, but also the promotion of the culture, values, history and art of that language. In this context, Yunus Emre Institute fulfills a significant mission in tha instruction of Turkish as a foreign language. The Institute that has offices in 58 locations around the world, collaborates with universities in countries with no local office and supports Turkish language instruction. Turkish Language and Literature Departments at various foreign universities, Turcology departments and schools affiliated to the Maarif Foundation are among the schools where Turkish language is instructed. In recent years, the demand to learn Turkish has increased due to the growth in strategic importance of Turkey, as well as the interest in Turkish TV series. To achieve success in education, it is extremely important to provide instruction with learner traits based contemporary educational approaches, methods and techniques. The key to success is to identify problems and to suggest solutions for these problems. Previous studies that aimed to identify the problems in Turkish language instruction were primarily on problems in Turkish language instruction in Turkey and two studies conducted abroad were on the problems experienced in these two respective countries. Thus, since there is no study that aimed to determine the problems in Turkish language instruction abroad in the literature, the present study could fill an important gap in the field. The qualitative data collected from professors who instructed Turkish as a foreign language abroad in various countries allowed to identify the associated problems in detail and offer solutions. Demirel (1993) reported that the success of foreign language instruction was dependent on the use of the basic principles and methods in the classroom, and the basic principles included a series of propositions determined based on the findings reported by language and education scholars in previous studies. This study was considered important due to the fact that the problems encountered in the instruction of Turkish abroad and associated solution were learned from the faculty who personally instructed Turkish and as determined by Demirel (1993), the requirement of the findings that would indicate the basic principles in foreign language achievements and associated propositions. When the problems are identified in detail and the proposed solutions are analyzed, the educators could design instruction, the researchers could work on these, the administrators, the program developers and the book authors could act based on these problems and the solutions.

Based on the above-mentioned information, the present study aimed to identify the problems experienced in four basic language skills and grammar in the Turkish instruction in universities abroad, and to offer solutions to these problems.

The phenomenology method, a qualitative research design, was employed in the study. According to Cropley, phenomenology focuses on phenomena that we are 
aware of but do not have in-depth and detailed knowledge on. In phenomenological studies, data sources may include individuals or groups who experienced the phenomenon and could express or reflect this phenomenon (Cited by Yildirım \& Şimşek, 2005).

The study data were collected with a semi-structured interview form developed by the author based on a literature review. The qualitative data were analyzed with content analysis.

In the study, it was determined that the prominent problems associated with listening, speaking, reading, writing and grammar instruction and university applications included 'the employment of a single type of sound recording, sound recording, lack of or inadequacy of listening devices', 'problems associated with the difficulties that students experienced in vocalizing foreign sounds (especially g, $\breve{g}, 1$, i, u, ü, o, ö, p sounds)' ,'pronunciation, accent, intonation errors when reading aloud,' 'reading only the texts available in the textbook,' ' low writing self-efficacy, writing anxiety, lack of interest, negative attitudes towards writing, frequent repetition of grammatical mistakes, previously learned foreign language topics or mother tongue preventing progress, negative attitude of students, lack of motivation, high level of anxiety, lack of technical and technological support, and problems associated with the curricula. The prominent solution suggestions for these problems included providing the required technical and audio recording devices for listening, determination of the speech topics based on student interests, inclusion of more diverse topics, novel reading books adequate for the student level, revision of the curricula and the textbooks that are functional and adequate for the student level, further writing exercises in topics of student interest based on process-based writing instruction, providing adequate feedback, grammar education based on four basic language skills, adequate physical and technological facilities, technical support, providing textbooks and resources on time, and reorganization of the curricula and associated resources.

In the present study, the problems experienced during the instruction of Turkish as a foreign language abroad were determined and problem solutions were determined. It was recommended for the instructors of Turkish as a foreign language, curriculum developers and textbook authors to consider the solutions presented in the study.

In the present study, the data included the views of 18 faculty members from 12 countries. The study should be considered as a first step, further data should be collected from all Turkish language instructors abroad about their problems and solution suggestions, and the curricula and textbooks should be reviewed based on contemporary Turkish education and instruction approaches in future workshops.

Since it was observed that there were problems associated with the Turkish alphabet, in other words, language-specific sounds, it is necessary to develop material for Turkish instruction specific for the instruction location in addition to the existing instruction material. 
In the instruction of Turkish as a foreign language abroad, the Turcology department curricula should be revised, and these curricula should be reviwed within bilateral relations that would be established with these countries. 